\title{
Electrodeposited, Ni-based, non-noble metal coatings as cathodes for hydrogen evolution in chlor-alkali electrolysis
}

\begin{abstract}
The hydrogen evolution reaction (HER) has been investigated on two types of electrodeposited, $\mathrm{Ni}$ based, non-noble metal coatings: composite coatings with inclusion of $\mathrm{MoO}_{2}$ particles and electrodeposited NiSn alloy coatings, in order to find suitable replacement for noble metal coatings (commercial De Nora's $\mathrm{Ni}_{-} \mathrm{RuO} \mathrm{O}_{2}$ electrode (DN)), as cathodes for industrial application in the zero-gap membrane cell for chlor-alkali electrolysis. Some samples of both types of cathodes showed better catalytic activity for the HER than the DN electrode under the conditions of industrial applications: 32 mass $\% \mathrm{NaOH}$ at $90^{\circ} \mathrm{C}$ and $j=-0.3 \mathrm{~A} \mathrm{~cm}^{-2}$. Since lower overvoltage for the HER is not the only criteria for successful application in industrial electrolysis, service life test (SLT), simulating long time operation of cathodes, has been applied for both types of cathodes. It has also been shown that certain samples of both types of cathodes could be promising replacement for the commercial DN electrode since they showed better performance during the SLT.
\end{abstract}

Keywords: Hydrogen evolution, $\mathrm{Ni}-\mathrm{MoO}_{2}$ composite coatings, NiSn ally coatings, service life test

\section{INTRODUCTION}

One of the most important industrial processes is chlor-alkali electrolysis for chlorine production in the zero-gap membrane cells [1-3]. In this process an ion-exchange membrane separates the anode and the cathode compartments and gaseous hydrogen is produced in cathode compartment from 30-32 mass \% caustic soda solution at a typical operating temperature of $90{ }^{\circ} \mathrm{C}$. Taking into account high efficiency for chlorine evolution due to low overvoltage on the DSA in the anodic compartment $[1,2]$, the efficiency of the cathodes is an important issue in this process, since the overpotential for the HER in the cathode compartment contributes significantly to the overall power consumption [3]. The efficiency of cathodes is a result of combination of certain activity and stability at the high current densities (3-6 $\left.\mathrm{kA} \mathrm{m}^{-2}\right)$ used in industrial applications. One of the main reasons for the loss of activity and stability of cathodes during long term operation is the so-called polarity inversion of the electrodes which takes place during the replacement of old electrodes of an electrolyzer with new ones in the zero-gap cells. During this operation anodes and cathodes are short-circuited, causing a reverse current flow which may damage the cathodes and negatively affect their activity for the HER [4]. The manufacturers can predict how often in a certain period of time such operation should be performed and, in accordance with that, design appropriate accelerated SLT for cathodes.

Author's address: ${ }^{1}$ Institute for Multidisciplinary Research University of Belgrade, Belgrade, K. Višeslava 1, Serbia, ${ }^{2}$ Faculty of Technology and Metallurgy University of Belgrade, Belgrade, Karnegijeva 4, Serbia

Received for Publication: 20. 12. 2013.

Accepted for Publication: 21. 02. 2014.
Such approach is missing in the literature and there are only few papers dealing with the SLT of electrode materials promising for use in industrial electrolysis [5-7]. The procedure is based on a sequence of galvanostatic polarizations in the HER range and cyclic voltammetry (CV's) in a wide potential range, from hydrogen evolution at its negative limit to oxygen evolution at its positive limit (reproducing the conditions of polarity inversion).

The HER has been so far investigated by our group on two types of electrodeposited, Ni-based, non-noble metal coatings: composite coatings with inclusion of $\mathrm{MoO}_{2}$ particles [5-9] and electrodeposited NiSn alloy coatings [10,11]. The purpose of such work was to find suitable replacement for the noble metal coatings, particularly for the commercial De Nora's $\mathrm{Ni}-\mathrm{RuO}_{2}$ cathode (deposited onto $\mathrm{Ni}$ mesh 40), as cathodes for industrial application in the zero-gap membrane cell for chloralkali electrolysis.

\section{EXPERIMENTAL}

\subsection{Composite $\mathrm{Ni}-\mathrm{MoO}_{2}$ coatings}

Composite coatings containing $\mathrm{MoO}_{2}$ particles (average size $200 \mathrm{~nm}$ ) were deposited at $j=-0.3 \mathrm{~A}$ $\mathrm{cm}^{-2}$ from the solution $0.2 \mathrm{M} \mathrm{NiCl}_{2}+2 \mathrm{M} \mathrm{NH}_{4} \mathrm{Cl}(\mathrm{pH}$ 3.8) containing $\mathrm{MoO}_{2}$ powder particles, in the apparatus (pilot plant of small dimensions) schematically presented in Fig. 1. The volume of the electrolyte in the cell for deposition was approximately $20 \mathrm{dm}^{-3}$. The electrolyte was circulated with the pump with a maximum flow rate of $0.83 \mathrm{dm}^{3} \mathrm{~s}^{-1}$ (a). The flow rate in the cell was measured with a flow meter (a), being $0.33 \mathrm{dm}^{3} \mathrm{~s}^{-1}$. Additional mixing of the electrolyte was provided by the air flow of $0.17 \mathrm{dm}^{3}$ $\mathrm{s}^{-1}$ through two pipes with small openings facing the bottom of the cell in order to remove eventually 
precipitated $\mathrm{MoO}_{2}$ particles from the bottom of the cell and to force particles to float and circulate with the electrolyte (b). The temperature of the electrolyte was kept constant by the thermocouple, heater and the control unit (a). The $\mathrm{Ni} 40$ mesh cathode, connected to a Ni holder (frame) (c), was placed between two $\mathrm{Ni}$ anode plates, as is schematically presented in (b). A home made power supply, with the ripple smaller than $1 \%$, was used for applying necessary current/voltage.

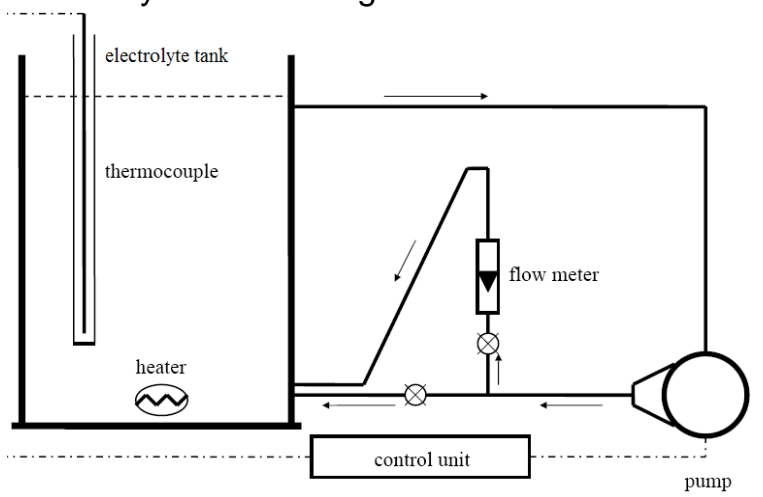

a)

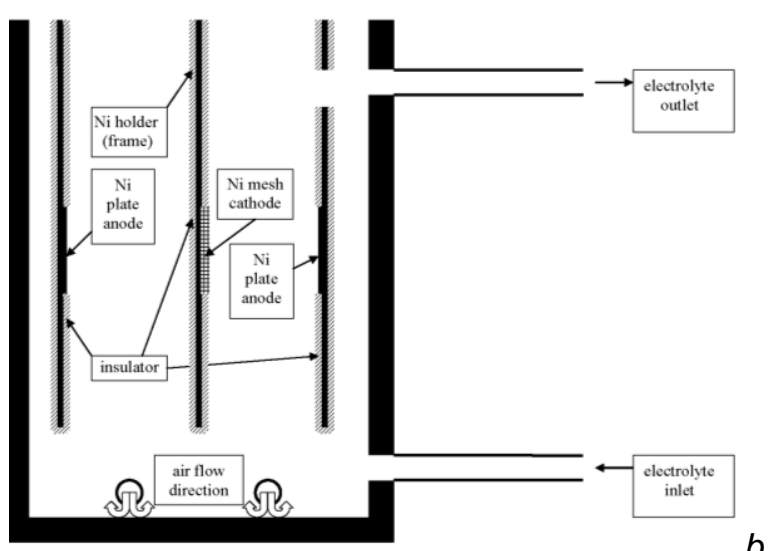

b)

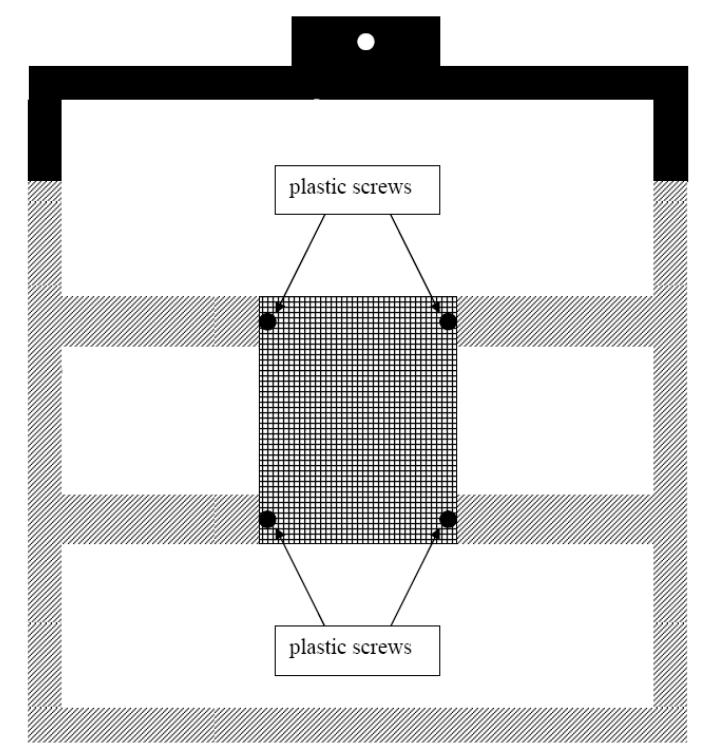

c)

Fig. 1. Schematic presentation of the apparatus for deposition of $\mathrm{Ni}-\mathrm{MoO}_{2}$ composite coatings.
Four samples were deposited under different conditions. Samples 1 and 2 were deposited from the bath with freshly added $\mathrm{MoO}_{2}$ (after $1 \mathrm{~h}$ of electrolyte circulation), while deposition of samples 3 and 4 started $24 \mathrm{~h}$ after $\mathrm{MoO}_{2}$ addition. It appeared that aging of the electrolyte of at least 24 $h$ is necessary for better incorporation of $\mathrm{MoO}_{2}$ particles in the deposit.

\subsection{NiSn alloy coatings}

Deposition of the NiSn coatings at constant current densities was performed onto $\mathrm{Ni} 40$ mesh electrodes with the potentiostat Reference 600 and software PHE 200 (Gamry Instruments) in the cell with two Pt counter electrodes (dimensions $2.5 \times 4$ $\mathrm{cm}$ ), placed parallel to the working electrode (dimensions $2 \times 3 \mathrm{~cm}$ ) in the solution containing 0.6 $\mathrm{mol} \mathrm{dm}{ }^{-3} \mathrm{~K}_{4} \mathrm{P}_{2} \mathrm{O}_{7}+0.3 \mathrm{~mol} \mathrm{dm}{ }^{-3} \mathrm{NiCl}_{2} \cdot 6 \mathrm{H}_{2} \mathrm{O}+0.1$ $\mathrm{mol} \mathrm{dm}{ }^{-3} \mathrm{SnCl}_{2} \cdot 2 \mathrm{H}_{2} \mathrm{O}+0.3 \mathrm{~mol} \mathrm{dm}^{-3}$ $\mathrm{NH}_{2} \mathrm{CH}_{2} \mathrm{COOH}$ of $\mathrm{pH}$ 6.7. During the deposition of samples the potential between the working and reference electrode was measured. Saturated calomel electrode (SCE) was used as the reference electrode, connected to the working electrode by means of Luggin capillary. Four samples were deposited: $\mathrm{NiSn}(10)$ at $j=-10 \mathrm{~mA} \mathrm{~cm}{ }^{-2}$, $\mathrm{NiSn}(30)$ at $j=-30 \mathrm{~mA} \mathrm{~cm}{ }^{-2}, \mathrm{NiSn}(60)$ at $j=-60 \mathrm{~mA}$ $\mathrm{cm}^{-2}, \mathrm{NiSn}(100)$ at $j=-100 \mathrm{~mA} \mathrm{~cm}$, each of them to the total charge of $70 \mathrm{C} \mathrm{cm}^{-2}$. All chemicals were p.a. quality. Certain procedure for solution preparation should be followed: the first component to be dissolved in extra pure UV water (Smart2PureUV, TKA) was $\mathrm{K}_{4} \mathrm{P}_{2} \mathrm{O}_{7}$; second component was $\mathrm{NH}_{2} \mathrm{CH}_{2} \mathrm{COOH}$; after that $\mathrm{NiCl}_{2} \cdot 6 \mathrm{H}_{2} \mathrm{O}$ was added and finally $\mathrm{SnCl}_{2} \cdot 2 \mathrm{H}_{2} \mathrm{O}$. After addition of all chemicals the $\mathrm{pH}$ was 6.7 .

All $\mathrm{Ni} 40$ mesh substrates were only shortly etched in 1:3 mixture of $\mathrm{H}_{2} \mathrm{O}: \mathrm{HNO}_{3}$ and washed with distilled water before the deposition.

\subsection{Polarization characteristics of the HER}

\subsubsection{Polarization characteristics of the HER onto $\mathrm{Ni}-\mathrm{MoO}_{2}$ coatings}

The polarization characteristics of the HER onto $\mathrm{Ni}-\mathrm{MoO}_{2}$ samples were tested in 32 mass \% $\mathrm{NaOH}$ solution in extra pure UV water at the temperature of $90{ }^{\circ} \mathrm{C}$ (industrial electrolyte). Electrodes were first submitted to hydrogen evolution at a constant current density $j=-0.3 \mathrm{~A} \mathrm{~cm}^{-2}$ for $0.5 \mathrm{~h}$ and after such pre-electrolysis polarization curves were recorded using the same potentiostat and DC 105 software. The following procedure of the polarization curve measurements was used: (1) sweeping potential with $1 \mathrm{mV} \mathrm{s}^{-1}$ from the potential of $-1.14 \mathrm{~V}$ to the value of $-1.34 \mathrm{~V}$ and recording the current (current interrupt technique was used for IR drop correction). This procedure was mainly used 
to estimate the most negative potential to start the second procedure; (2) starting from the most negative potential (depending on the catalytic activity of the investigated coatings) the potential was changed in steps of $10 \mathrm{mV}$ towards less negative values; at each potential current response was recorded for $150 \mathrm{~s}$ and the value recorded at the end was used to produce the polarization curve; the $j$ vs. $t$ response at each applied potential was recorded with the current interrupt being on (IR drop correction). The same procedure was applied for the commercial DN electrode.

\subsubsection{Polarization characteristics of the HER onto NiSn coatings}

The polarization characteristics of the HER onto NiSn samples were tested in the same electrolyte under the same conditions as for $\mathrm{Ni}$ $\mathrm{MoO}_{2}$ samples with the same potentiostat and software. Three-compartment cell, specially designed for such NiSn samples (deposited onto $\mathrm{Ni}$ 40 mesh) was used: working electrode of the surface area of $1 \mathrm{~cm}^{2}$ was placed in a central compartment together with the Luggin capillary; two Pt mesh counter electrodes of larger areas were placed in the separate compartments each (parallel to the working electrode mesh), so that oxygen evolved at the counter electrode cannot enter the working electrode compartment. SCE was placed in a side compartment connected to the central one through a bridge and a Luggin capillary, and was kept at the room temperature. NiSn coatings were first submitted to the HER at a constant current density $j=-0.3 \mathrm{~A} \mathrm{~cm}^{-2}$ for $800 \mathrm{~s}$ (step 1), followed by the HER at a constant potential. The value of potential was adjusted to produce cathodic current density slightly higher than $-0.3 \mathrm{~A} \mathrm{~cm}^{-2}$ (step 2). After such pre-electrolysis polarization curves were recorded by sweeping potential with $1 \mathrm{mV} \mathrm{s}^{-1}$ from the potential applied in step 2 to the value slightly more positive than the corrosion potential and recording the current density. After recording polarization curves potential was corrected for the IR drop using the value of ohmic resistance obtained from the EIS measurements (see section 2.4.). The same procedure was applied for the commercial DN electrode.

\subsection{SEM and EDS analysis of the NiSn coatings}

The appearance of coated surfaces and the cross-sections of the coatings were investigated by SEM, Tescan, VEGA TS 5130 MM equipped with an energy-dispersive X-ray spectroscopy (EDS), INCAPentaFET-x3 (Oxford Instruments). For the SEM and EDS analysis of a cross-section, samples were sealed in the epoxy resin and polished down to the alumina suspension of $0.05 \mu \mathrm{m}$ and kept in an ultrasonic bath for $10 \mathrm{~min}$. to remove traces of polishing alumina.

\subsection{EIS measurements}

The EIS measurements for the HER were performed in the same solution and the same cell with the same potentiostat and EIS 300 software in the frequency range from $10 \mathrm{kHz}$ to $0.1 \mathrm{~Hz}$ with 20 points per decade at the amplitude of $5 \mathrm{mV}$ RMS. The real $\left(Z^{\prime}\right)$ and imaginary $\left(Z^{\prime \prime}\right)$ components of the electrochemical impedance spectra in the Nyquist plot were analyzed using the complex nonlinear least squares (CNLS) fitting program (EIS 300) to simulate the equivalent resistances and capacitances. EIS measurements were performed at a constant potential of $-1.20 \mathrm{~V}$. Before the EIS measurements, electrodes were kept at the same potential for $100 \mathrm{~s}$ to establish stable current density response.

\section{5. $S L T$}

\subsubsection{SLT for $\mathrm{Ni}-\mathrm{MoO}_{2}$ coatings}

In this case different approach for SLT of hydrogen evolution cathodes was applied in comparison with that of Antozzi et al. [5]. Experiments were performed in 32 mass $\% \mathrm{NaOH}$ at $90{ }^{\circ} \mathrm{C}$ in a following way: electrode was kept at $j$ $=-0.3 \mathrm{~A} \mathrm{~cm}^{-2}$ for $0.5 \mathrm{~h}$ and immediately after that $\mathrm{a}$ constant potential $E=-1.27 \mathrm{~V}$ was applied for 300 $s$ and current density vs. time response (corrected for the IR drop using "current interrupt technique") has been recorded. After that, electrode was cycled ( 5 cycles) in the potential region from $-1.25 \mathrm{~V}$ to $0.5 \mathrm{~V}$ with a sweep rate of $50 \mathrm{mV} \mathrm{s}^{-1}$. In the next step current density vs. time response at the potential $E=-1.27 \mathrm{~V}$ was again recorded for the same time (300 s). This procedure was repeated 5 times, until the number of cycles reached 25 . Instead of measuring the potential at $j=-0.3 \mathrm{~A} \mathrm{~cm}^{-2}$ after each 5 cycles, the values of current density at the end of current density vs. time responses were used as criteria for eventual degradation of the electrode during the oxidation process at the most positive potentials. The reason for such approach is simple: the potential response at $j=-0.3 \mathrm{~A} \mathrm{~cm}^{-2}$ depends on the position of the electrode versus the Luggin capillary (during this experiment IR drop correction using "current interrupt technique" is not possible), and if the distance between the electrode surface and the tip of the Luggin capillary is not always the same measured potential can vary up to $30-50 \mathrm{mV}$ at such a high current density. Hence, in order to be sure that the distance between the electrode surface and the tip of the Luggin capillary is always the same (with the precision less than 0.1 $\mathrm{mm}$ ), a special cell must be designed and used. On the other side, if the current density vs. time response is measured at a constant potential with 
IR drop correction using "current interrupt technique" (as we did in our work) this factor cannot influence the results. Such SLT seems to be more appropriate for application in the industrial electrolysis, since it is not based on the EIS measurements and complex analysis of their results, as in the case of Ref. [5]. The same procedure was applied for the commercial DN electrode.

\subsubsection{SLT for NiSn coatings}

SLT experiments were performed in 32 mass \% $\mathrm{NaOH}$ at $90{ }^{\circ} \mathrm{C}$ in a following way (in a threecompartment cell described in the section 2.2.2.): step (1) - electrode was kept at $j=-0.3 \mathrm{~A} \mathrm{~cm}^{-2}$ for $600 \mathrm{~s}$ and corresponding potential response was recorded; step (2) - electrode was kept at a constant potential of $-1.20 \mathrm{~V}$ for $100 \mathrm{~s}$; step (3) EIS measurement was performed at the same potential; step (4) - electrode was cycled (5 cycles) in the potential range from $-1.20 \mathrm{~V}$ (hydrogen evolution) to $0.45 \mathrm{~V}$ (oxygen evolution) with a sweep rate of $50 \mathrm{mV} \mathrm{s}^{-1}$. This procedure (steps (1) to (4)) was repeated 5 times, until the number of cycles reached 25 . After the $25^{\text {th }}$ cycle electrode was kept at $j=-0.3 \mathrm{~A} \mathrm{~cm}^{-2}$ for $600 \mathrm{~s}$ and corresponding (last) potential response was recorded. Potential response measured at $j=-0.3$ $\mathrm{A} \mathrm{cm}{ }^{-2}$ for $600 \mathrm{~s}$ was corrected for the IR drop using the value of ohmic resistance determined from the high frequency end of the Nyquist plots recorded at a constant potential of $-1.20 \mathrm{~V}$ for each electrode. This procedure was performed for all NiSn samples, as well as for the commercial DN electrode. The value of potential recorded at the end of the galvanostatic pulse (at $600^{\text {st }} \mathrm{s}$ ) was used for comparison in the SLT.

\section{RESULTS AND DISCUSSION}

\subsection{Polarization characteristics of the HER onto $\mathrm{Ni}-\mathrm{MoO}_{2}$ coatings}

Polarization characteristics of the HER for samples $1-4$, recorded in 32 mass $\% \mathrm{NaOH}$ at 90 ${ }^{\circ} \mathrm{C}$ and corrected for IR drop, are presented in Fig. 2a. Significant decrease of overvoltage for the HER is recorded for samples 3 and 4 . By comparing polarization diagrams for the DN electrode $(\boldsymbol{\square})$, and the best sample $4(O)$ one can see that polarization diagrams are almost identical, Fig. $2 b$, indicating that $\mathrm{Ni}-\mathrm{MoO}_{2}$ composite coatings, deposited under conditions described above in the apparatus presented in Fig. 1, could be promising replacement for the commercial cathodes based on the $\mathrm{Ni}-\mathrm{RuO}_{2}$ composite coatings [5-9]. Taking into account that in the industrial electrolysis the current density for the HER is usually $-0.3 \mathrm{~A} \mathrm{~cm}$, considering polarization curves presented in Fig.
$2 \mathrm{~b}$, it could be concluded that the overvoltage for the HER onto $\mathrm{Ni}-\mathrm{MoO}_{2}$ composite coating is for about $20 \mathrm{mV}$ lower than that on the commercial DN cathode.

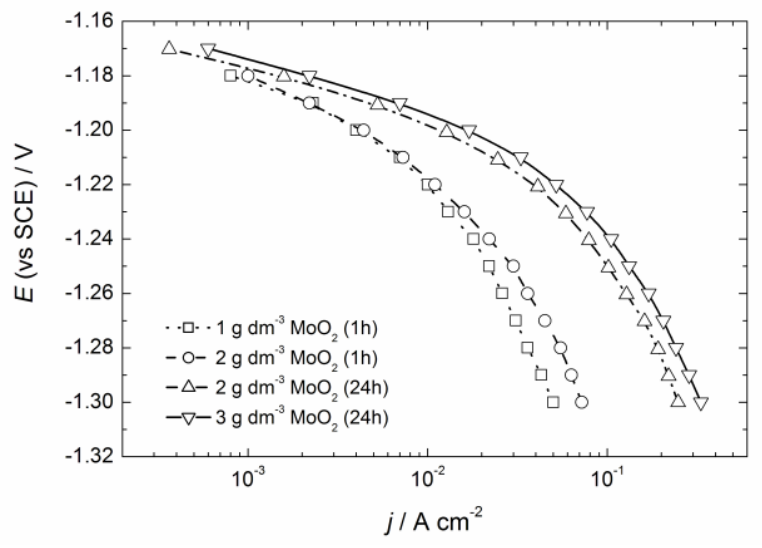

a)

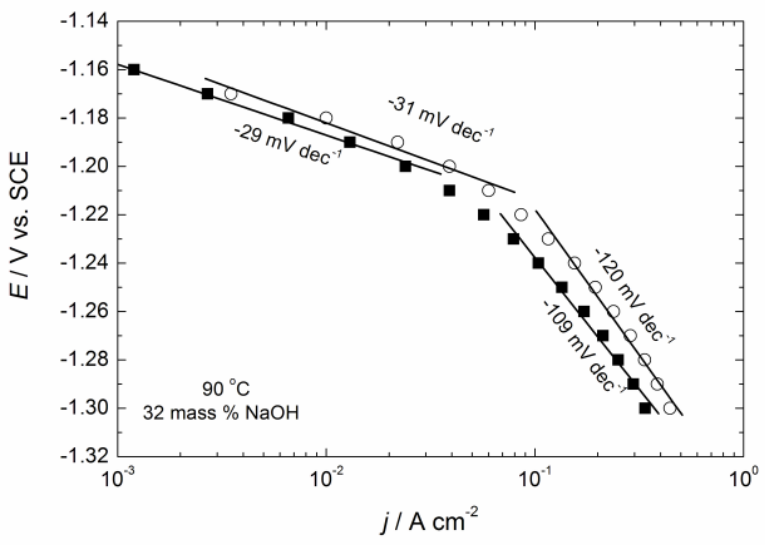

b)

Fig. 2. (a) Polarization diagrams for the HER measured on samples 1-4. (b) Polarization diagrams for the HER measured on sample $4(\bigcirc)$ compared with that recorded for the commercial De Nora's $\mathrm{Ni}-\mathrm{RuO}_{2}$ cathode (ם).

\subsection{SLT for the $D N$ cathode and the $\mathrm{Ni}-\mathrm{MoO}_{2}$ coatings}

After recording polarization curves electrodes were submitted to the SLT, as explained in the section 2. Since in most industrial plants automatic cathodic protection of cathodes is switched on during the shut-downs, the SLT is designed to estimate the efficiency of cathodes during so-called polarity inversion which takes place during the replacement of old electrodes of an electrolyzer with new ones in the zero-gap cells (see section 1.).

\subsubsection{Results obtained for the DN electrode}

The cyclic voltammograms (CV's) recorded during the first cycling procedure (cycles 1-5) are presented in Fig. 3a. As can be seen the $1^{\text {st }}$ cycle is characterized by high current density peaks (la 
and Ila) around $-0.9 \mathrm{~V}$ and $-0.8 \mathrm{~V}$ respectively, which become much smaller already at the second cycle and cycles 2-5 are practically identical. Taking into account that before the first cycling procedure electrode was only cathodically polarized at $j=-0.3 \mathrm{~A} \mathrm{~cm}^{-2}$ for $0.5 \mathrm{~h}$ and immediately after that at $E=-1.27 \mathrm{~V}$ for $300 \mathrm{~s}$ with the current density for the HER of about $-0.18 \mathrm{~A}$ $\mathrm{cm}^{-2}$, the peaks la and Ila are most likely the consequence of the formation of $\alpha$ - and $\beta$ - Ni(OH) respectively, and oxidation of huge amount of adsorbed and absorbed hydrogen during the HER. The peaks $\mathbf{1 a}$ and $\mathbf{2 a}$, present on cycles $2-5$ are the consequence of the formation of $\alpha-\mathrm{Ni}(\mathrm{OH})_{2}, \beta-$ $\mathrm{Ni}(\mathrm{OH})_{2}$ and $\mathrm{NiOOH}$ (oxidation of $\mathrm{Ni}$ ), while the peak $2 c$ corresponds to the reduction of $\mathrm{NiOOH}$, which is typical for the Ni based cathodes [12-20]. The CV's recorded during the last cycling procedure (cycles 21-25) are presented in Fig. 3b. In this case the difference between the $1^{\text {st }}$ and subsequent cycles is very small, probably due to irreversible formation of $\beta$ - $\mathrm{Ni}(\mathrm{OH})_{2}$ film on the top of the electrode surface which prevents hydrogen oxidation reaction to take place, or indicating that the amount of adsorbed and absorbed hydrogen is

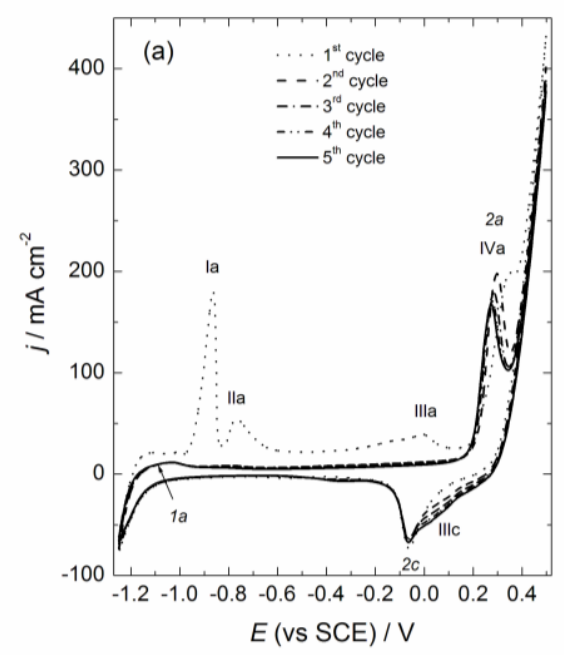

negligible in comparison with that during the cycle number 1 (Fig. 3a). Such behavior is in accordance with the values of current densities recorded after holding electrode at $E=-1.27 \mathrm{~V}$ for $300 \mathrm{~s}$ (see Fig. $5)$. It is interesting to note that the peaks Illa are well defined on the $1^{\text {st }}$ and $21^{\text {st }}$ cycle (as well as on the $6^{\text {st }}, 11^{\text {th }}$ and $16^{\text {th }}$ cycle - not shown) indicating that this peak exists only on the first cycle in the series of cycles. It probably corresponds to the additional oxidation of ruthenium oxide on the electrode surface and this process probably occurs under the peak IVa (2a) during the subsequent cycles [21]. It's counter part, reflecting reduction of additionally formed oxide, peak IIIc, is seen to increase during the first series of cycles (Fig. 3a) and becomes well defined during the last series of cycles (Fig. 3b). The presence of the peak IIIc together with the peaks $\mathbf{2 a}$ and $\mathbf{2 c}$ could be detected on the $\mathrm{CV}$ of $\mathrm{Ni}-\mathrm{RuO}_{2}$ coating electrodeposited from chloride bath $\left(45 \mathrm{~g} \mathrm{dm}^{-3}\right.$ $\mathrm{NiCl}_{2}+0.37 \mathrm{~g} \mathrm{dm}^{-3} \mathrm{HCl}+30 \mathrm{~g} \mathrm{dm}^{-3} \mathrm{H}_{3} \mathrm{BO}_{3}+0.03 \mathrm{~g}$ $\mathrm{dm}^{-3}$ sodium dodecyl sulfate) [21], while on the $\mathrm{CV}$ 's of the $\mathrm{Ni}-\mathrm{RuO}_{2}$ coatings electrodeposited from $0.2 \mathrm{M} \mathrm{NiCl} 2+2 \mathrm{M} \mathrm{NH}{ }_{4} \mathrm{Cl}$ bath $[5,22]$ only peaks $2 a$ and $2 c$ are present.

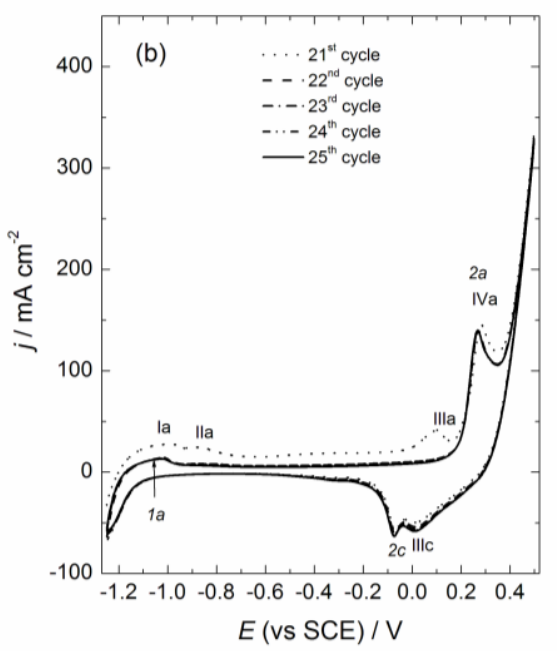

Fig. 3. CV's recorded onto DN cathode coating with the sweep rate of $50 \mathrm{mV} \mathrm{s}^{-1}$ in the solution of 32 mass $\% \mathrm{NaOH}$ at $90^{\circ} \mathrm{C}$ in the potential region from hydrogen evolution (-1.25 V) to oxygen evolution (0.5 V): (a) first 5 cycles (marked in the figure); (b) last 5 cycles (marked in the figure).

\subsubsection{Results obtained for the $\mathrm{Ni}-\mathrm{MoO}_{2}$ composite coatings}

The CV's recorded during the cycling procedures are similar to those presented for the DN electrode. The typical CV's recorded during the first cycling procedure (cycles 1-5) are presented in Fig. 4a. For these two electrodes cycles 2-5 are not practically identical (compared to the DN electrode), but a small change in the position and the peak current density values are recorded. The same conclusion concerning the shape of the CV's as the one given for the DN electrode is valid for this electrode. The typical CV's recorded during the last cycling procedure (cycles 21-25) are presented in Fig. 4b. In this case the difference between the $1^{\text {st }}$ and subsequent cycles is not as small as in the case of the DN electrode, indicating that the oxidation of adsorbed and absorbed hydrogen is not as negligible as in the case of the DN electrode. The peak IIIc, corresponding most likely to the reduction of $\mathrm{MoO}_{2}$ is partially masked by the reductoion of $\mathrm{NiOOH}$ into $\beta-\mathrm{Ni}(\mathrm{OH})_{2}$ [23]. 

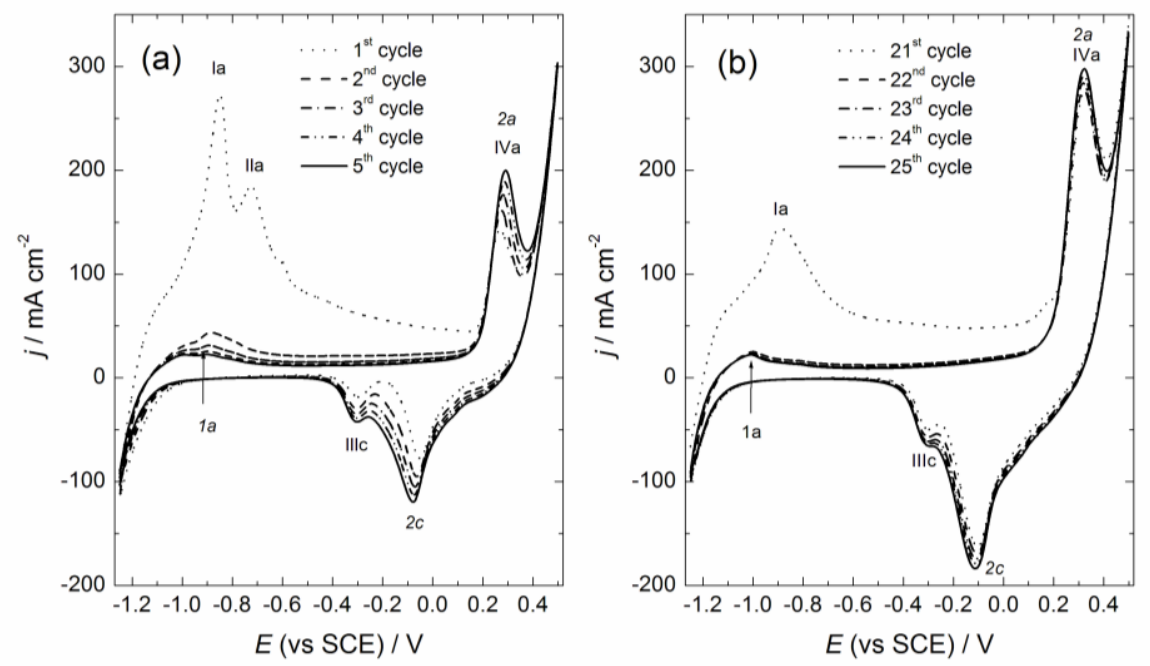

Fig. 4. CV's recorded onto $\mathrm{Ni}-\mathrm{MoO}_{2}$ cathode coating with the sweep rate of $50 \mathrm{mV} \mathrm{s}^{-1}$ in the solution of 32 mass \% NaOH at $90^{\circ} \mathrm{C}$ in the potential region from hydrogen evolution $(-1.25 \mathrm{~V})$ to oxygen evolution $(0.5$ $V)$ : (a) first 5 cycles (marked in the figure); (b) last 5 cycles (marked in the figure).

Considering the CV's presented in Figs. 3 and 4 following observations could be made:

- A common characteristic for all electrodes is the difference between the shape of the first and subsequent cycles, with the ones for DN electrode being the most pronounced;

- for the DN electrode first cycle is characterized with the appearance of four anodic peaks (la, Ila, IIla and IVa), while for the $\mathrm{Ni}-\mathrm{MoO}_{2}$ electrodes the first cycle is characterized with the appearance of three anodic peaks (la, Ila and IVa). For both electrodes subsequent cycles $\left(2^{\text {nd }}-5^{\text {th }}\right.$ and $\left.21^{\text {st }}-25^{\text {th }}\right)$ are characterized with the anodic peaks $\mathbf{1 a}$ and $\mathbf{2 a}$, as well as with the cathodic peak $2 c$ typical for pure $\mathrm{Ni}$ electrode;

- among the appearance of the anodic peak Illa the main difference in the behavior of the $\mathrm{RuO}_{2}$ based (DN) and Mo-oxide based $\left(\mathrm{Ni}-\mathrm{MoO}_{2}\right)$ electrodes is the appearance and the position of the cathodic peak IIIc. For the $\mathrm{Ni}-\mathrm{MoO}_{2}$ electrode the peak IIIc is positioned at more negative potential of about $-0.33 \mathrm{~V}$ and is also seen to grow with the number of cycles (Fig. 4) together with the peaks $2 a$ and $2 c$.

Similar and reproducible shapes of the CV's for the $\mathrm{Ni}, \mathrm{DN}$, and $\mathrm{Ni}-\mathrm{MoO}_{2}$ electrodes (Figs. 3 and 4) confirm that at $\mathrm{MoO}_{2}$ containing electrode, as well as at $\mathrm{RuO}_{2}$ containing electrode, the same surface reactions take place without clear evidence for anodic dissolution of either molybdenum or ruthenium oxides.

After each set of 5 cycles electrodes were again submitted to the potential $E=-1.27 \mathrm{~V}$ for 300 $s$ and corresponding $j-t$ responses were recorded. The values of cathodic current densities obtained at the end of the $j$ - $t$ responses for the $\mathrm{DN}$ and $\mathrm{Ni}$ $\mathrm{MoO}_{2}$ electrodes are presented in Fig. 5. The current density for the DN electrode continuously decreases with the number of cycles, while for the $\mathrm{Ni}-\mathrm{MoO}_{2}$ electrode such decrease occurs only during the first 5 cycles, with the current density being practically constant from $5^{\text {th }}$ to $25^{\text {th }}$ cycle. Such behavior indicates that the main degradation of $\mathrm{Ni}-\mathrm{MoO}_{2}$ electrode takes place during the first 5 cycles, while the degradation of the DN electrode occurs during the whole cycling period. Hence, considering Fig. 5, it could be concluded that both electrodes become damaged during the SLT. The decrease in cathodic current density for DN electrode amounted to approximately $53 \%$ of the initial value, while for the $\mathrm{Ni}-\mathrm{MoO}_{2}$ electrode it amounted to $55 \%$ of the initial value. It should also be stated that the $\mathrm{Ni}-\mathrm{MoO}_{2}$ electrode showed better characteristic during the SLT. The loss of activity of these electrodes is comparable with the results obtained for Pt-based cathodes [5].

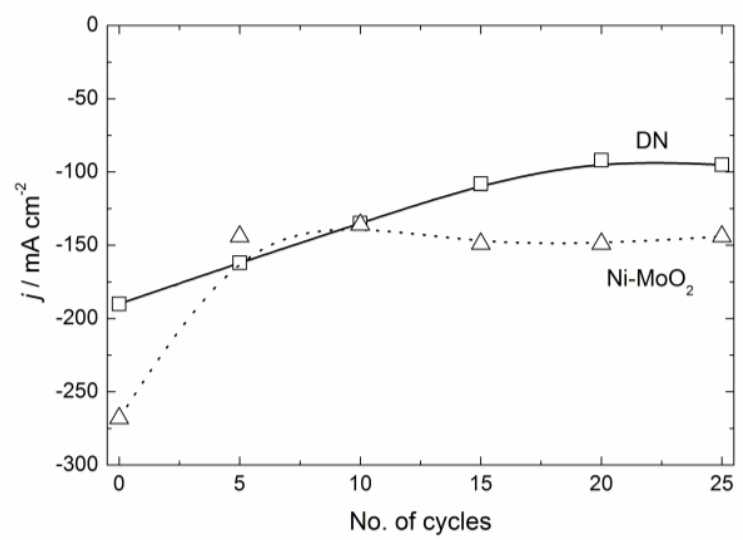

Fig. 5. The results of the SLT for the DN electrode $(\square)$ and composite $\mathrm{Ni}-\mathrm{MoO}_{2}$ coating (sample 4, $(\triangle)$ ). 


\subsection{SEM-EDS analysis of the Ni-MoO 2 composite coating before and after the SLT}

The morphology of the $\mathrm{Ni}-\mathrm{MoO}_{2}$ composite coating (sample 4), recorded immediately after deposition, is presented in Fig. 6a. As marked in the figure two types of deposit could be recognized on the surface: part with no cracks over each wire of the mesh ( $\mathrm{Ni}$ rich parts) and part with some cracks at the positions of contact between two $\mathrm{Ni}$ wires of the mesh $\left(\mathrm{MoO}_{2}\right.$ rich parts). Regions with no cracks are characterized with lower percentage of molybdenum and oxygen, while the average composition of the regions with cracks showed very low percentage of nickel and higher percentages of Mo and $O$. It is quite difficult to uniformly incorporate $\mathrm{MoO}_{2}$ particles in the Ni deposit on the $\mathrm{Ni} 40$ mesh, since all places of the surface are not equally accessible to the $\mathrm{MoO}_{2}$ particles and $\mathrm{Ni}$ ions. As can be seen in Fig. $6 a$ the position of
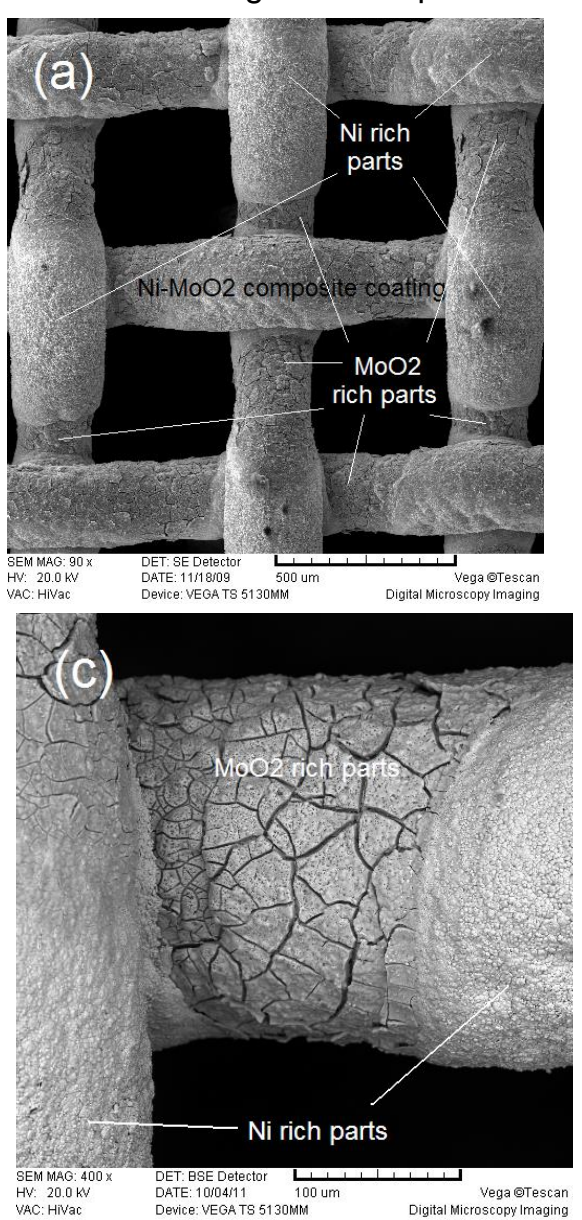

crossing two wires is the place where, because of the change of hydrodynamic conditions at this particular position, higher amount of $\mathrm{MoO}_{2}$ particles is embedded in the Ni deposit, probably as a result of lower real current density for $\mathrm{Ni}$ deposition.

The cross-section of the $\mathrm{Ni}$ rich part of the same coating is presented in Fig. 6b. As shown in the figure grey parts are rich in $\mathrm{Ni}$, while white parts are rich in Mo. The appearance of this coating didn't change with the time, indicating absence of internal stress in the coating. The appearance of the coating after HER at $j=-0.3 \mathrm{~A} \mathrm{~cm}^{-2}$ for $40 \mathrm{~h}$ and after the SLT are presented in Figs. $6 \mathrm{c}$ and $6 \mathrm{~d}$, respectively. As can be seen the appearance of the coating did not change after HER at $j=-0.3 \mathrm{~A} \mathrm{~cm}^{-2}$ for $40 \mathrm{~h}$ (Fig. 6c), while Mo rich parts were mainly destroyed and dropped off from the $\mathrm{Ni}$ mesh surface after the SLT (Fig. 6d).
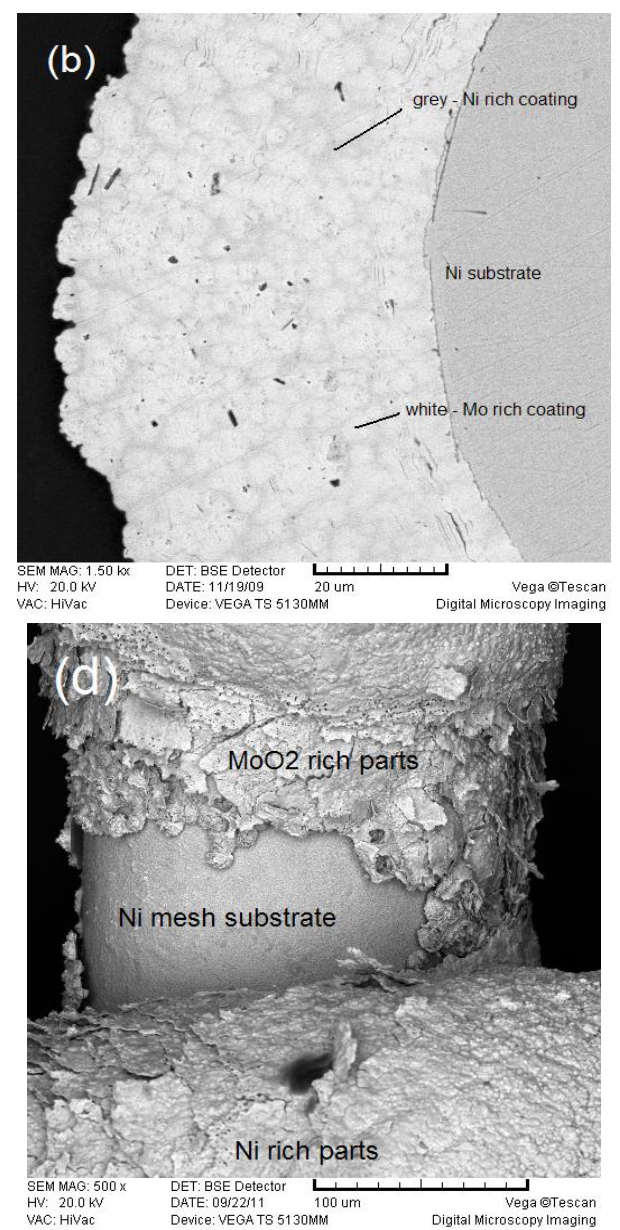

Fig. 6. (a) SEM of the surface of the $\mathrm{Ni}-\mathrm{MoO}_{2}$ composite coating recorded immediately after deposition. (b) Back-scatter SEM of the cross-section of the Ni rich part of the coating. (c) SEM of the

$\mathrm{Ni}-\mathrm{MoO}_{2}$ surface after $40 \mathrm{~h}$ of the $\mathrm{HER}$ at $\mathrm{j}=-0.3 \mathrm{~A} \mathrm{~cm}^{-2}$. (d) SEM of the Ni-MoO surface after the SLT.

Taking into account the presence of large number of cracks in the Mo rich parts of the $\mathrm{Ni}-\mathrm{MoO}_{2}$ coating, the loss of the coating (and consequently the loss of activity) is most likely due to erosion caused by the evolved gas. The mechanical damage was not caused by the evolved hydrogen bubbles as seen in Fig. 5c. However, during cycling procedure, the oxygen evolution reaction (OER) 
takes place on examined electrodes reaching very high current densities of $0.3-0.4 \mathrm{~A} \mathrm{~cm}^{-2}$ during anodic polarization. Unlike the HER, the OER is highly irreversible reaction and due to its very low exchange current density it takes place at overall catalyst surface without any diffusion limitation in the pores and cracks. So, the rapid evolution of oxygen on Mo rich parts of the $\mathrm{Ni}-\mathrm{MoO}_{2}$ coatings generated significant pressures within the porous coating causing its mechanical damage (erosion).

Hence, considering Figs. 5 and 6 it could be concluded that composite $\mathrm{Ni}-\mathrm{MoO}_{2}$ coating represents promising replacement for the commercial DN cathode in chlor-alkali electrolysis.

\subsection{Deposition of NiSn alloy coatings}

According to the literature [24] standard potential of the Ni deposition is $-0.23 \mathrm{~V}$ vs. SHE, while that for $\mathrm{Sn}$ amounts to $-0.1364 \mathrm{~V}$ vs. SHE and accordingly $\mathrm{Ni}$ is less noble metal. Taking into account that the overvoltage for $\mathrm{Ni}$ deposition [25] is much higher than that for Sn deposition [28], the difference between the potentials of deposition of these two metals should be larger than that of their standard potentials. In the data presented in Dean's Handbook of Chemistry [26] Ni forms two pyrophosphate complexes, $\left[\mathrm{Ni}\left(\mathrm{P}_{2} \mathrm{O}_{7}\right)\right]^{2-}$ and $\left[\mathrm{Ni}\left(\mathrm{P}_{2} \mathrm{O}_{7}\right)_{2}\right]^{6-}$ and three glycine complexes, $\left[\mathrm{Ni}\left(\mathrm{NH}_{2} \mathrm{CH}_{2} \mathrm{COO}\right)\right]^{+}, \quad\left[\mathrm{Ni}\left(\mathrm{NH}_{2} \mathrm{CH}_{2} \mathrm{COO}\right)_{2}\right]$ and $\left[\mathrm{Ni}\left(\mathrm{NH}_{2} \mathrm{CH}_{2} \mathrm{COO}\right)_{3}\right]^{-}$. There are limited data in the literature for different complexes of $\mathrm{Ni}$ and $\mathrm{Sn}$ in the pyrophosphate and glycine solutions [27]. Corresponding reactions for the formation of different complexes and their formation (stability) constants are given in the work of Duffield et al. [27]. All species and their stability constants used for the calculation of the distribution of different complexes in the solution containing $\mathrm{Sn}, \mathrm{Ni}$, pyrophosphate and glycine ions are listed in Table 1 [28].

The calculation of the distribution of complexes in the solution containing pyrophosphate and glycine, showed that $\left[\mathrm{Sn}\left(\mathrm{P}_{2} \mathrm{O}_{7}\right)_{2}\right]^{6-}$ is dominant complex with $\mathrm{Sn}$ at $\mathrm{pH}$ 8.0, while two complexes of $\mathrm{Ni}$ dominate: complex $\left[\mathrm{Ni}\left(\mathrm{P}_{2} \mathrm{O}_{7}\right)_{2}\right]^{6-}$, and complex $\left[\mathrm{Ni}\left(\mathrm{NH}_{2} \mathrm{CH}_{2} \mathrm{COO}\right)_{3}\right]^{-}$. The values of the equilibrium potentials $\left(E_{\text {eq }}\right)$ of prevailing complexes, calculated using explanations based on the Gibbs energy change for reaction of certain complex formation [29] (assuming that the ions activities are equal to their concentrations), are also presented in Table 1. As can be seen, the equilibrium potential for deposition of $\mathrm{Sn}$ by the reduction of $\left[\mathrm{Sn}\left(\mathrm{P}_{2} \mathrm{O}_{7}\right)_{2}\right]^{6-}$ complex is $-0.847 \mathrm{~V}$ vs. SCE, while the equilibrium potentials for the reduction of $\left[\mathrm{Ni}\left(\mathrm{P}_{2} \mathrm{O}_{7}\right)_{2}\right]^{6-}$ and $\left[\mathrm{Ni}\left(\mathrm{NH}_{2} \mathrm{CH}_{2} \mathrm{COO}\right)_{3}\right]^{-}$complexes are more positive, being about $-0.716 \mathrm{~V}$ vs. SCE and situation becomes opposite to that for deposition from the solution of simple ions. After the complexation $\mathrm{Ni}$ becomes more noble metal, while Sn becomes less noble one. Hence, the $\mathrm{Sn}$ would deposit from the complex $\left[\mathrm{Sn}\left(\mathrm{P}_{2} \mathrm{O}_{7}\right)_{2}\right]^{6-}$, while $\mathrm{Ni}$ would deposit simultaneously from two complexes, $\left[\mathrm{Ni}\left(\mathrm{P}_{2} \mathrm{O}_{7}\right)_{2}\right]^{6-}$ and $\left[\mathrm{Ni}\left(\mathrm{NH}_{2} \mathrm{CH}_{2} \mathrm{COO}\right)_{3}\right]^{-}$, in the presence of both complexing anions. The equilibrium potentials for deposition of $\mathrm{Sn}$ and $\mathrm{Ni}$ still differ for $0.131 \mathrm{~V}$. As already stated, because of high overvoltage for $\mathrm{Ni}$ deposition [25], it could be expected that two metals possess identical, or similar, potential of deposition. This is exactly the case for these two metals in the pyrophosphate-glycine solution. The polarization curve for $\mathrm{NiSn}$ alloy deposition onto $\mathrm{Ni}$ 40 mesh electrode from the solution $0.1 \mathrm{M} \mathrm{SnCl}_{2}+$ $0.3 \mathrm{M} \mathrm{NiCl}_{2}+0.6 \mathrm{M} \mathrm{K}_{4} \mathrm{P}_{2} \mathrm{O}_{7}+0.3 \mathrm{M} \mathrm{NH}_{2} \mathrm{CH}_{2} \mathrm{COOH}$ at $\mathrm{pH} 6.7$ is shown in Fig. 7 [11]. The deposition process commences at about $-0.83 \mathrm{~V}$ showing shoulder between about $-0.90 \mathrm{~V}$ and about $-1.00 \mathrm{~V}$ and increase of cathodic current density at more negative potentials. Four samples of the NiSn alloy coatings, of the total charge of $70 \mathrm{C} \mathrm{cm}^{-2}$ each, were deposited onto $\mathrm{Ni} 40$ mesh (marked in the figure): $\mathrm{NiSn}(10)-j=-10 \mathrm{~mA} \mathrm{~cm}{ }^{-2}, \mathrm{NiSn}(30)-j=-$ $30 \mathrm{~mA} \mathrm{~cm}^{-2}, \mathrm{NiSn}(60)-j=-60 \mathrm{~mA} \mathrm{~cm}^{-2}$ and $\mathrm{NiSn}(100)-j=-100 \mathrm{~mA} \mathrm{~cm}^{-2}$. In the inset are shown corresponding $E$ vs. $t$ responses.

Table 1 - All complexes present in the solution containing $0.1 \mathrm{MSnCl}_{2}+0.1 \mathrm{M} \mathrm{NiCl}_{2}+0.6 \mathrm{M} \mathrm{K}_{4} \mathrm{P}_{2} \mathrm{O}_{7}+0.3$ $M \mathrm{NH}_{2} \mathrm{CH}_{2} \mathrm{COOH}$, their concentrations, stability constants and equilibrium potentials $\left(E_{e q}\right)$ of prevailing complexes.

\begin{tabular}{|c|c|c|c|}
\hline Complexes & $\log \beta$ & Conc./M & $\begin{array}{c}E_{e q} / V \\
\text { vs. SCE }\end{array}$ \\
\hline$\left[\mathrm{H}\left(\mathrm{P}_{2} \mathrm{O}_{7}\right)\right]^{3-}$ & 8.14 & & \\
\hline$\left[\mathrm{H}_{2}\left(\mathrm{P}_{2} \mathrm{O}_{7}\right)\right]^{2-}$ & 14.01 & & \\
\hline$\left[\mathrm{H}_{3}\left(\mathrm{P}_{2} \mathrm{O}_{7}\right)\right]^{-}$ & 15.78 & & \\
\hline$\left[\mathrm{H}_{4}\left(\mathrm{P}_{2} \mathrm{O}_{7}\right)\right]$ & 16.63 & & \\
\hline$\left[\mathrm{H}\left(\mathrm{NH}_{2} \mathrm{CH}_{2} \mathrm{COO}\right)\right]$ & 9.64 & & \\
\hline$\left[\mathrm{H}_{2}\left(\mathrm{NH}_{2} \mathrm{CH}_{2} \mathrm{COO}\right)\right]^{+}$ & 12.05 & & \\
\hline$\left[\mathrm{Sn}\left(\mathrm{NH}_{2} \mathrm{CH}_{2} \mathrm{COO}\right) \mathrm{H}\right]^{2+}$ & 12.78 & & \\
\hline$\left[\mathrm{Sn}\left(\mathrm{NH}_{2} \mathrm{CH}_{2} \mathrm{COO}\right)\right]^{+}$ & 10.02 & & \\
\hline$\left[\mathrm{Sn}\left(\mathrm{P}_{2} \mathrm{O}_{7}\right)\right]^{2-}$ & 13.05 & 0.007 & -0.847 \\
\hline$\left[\mathrm{Sn}\left(\mathrm{P}_{2} \mathrm{O}_{7}\right) \mathrm{H}\right]^{-}$ & 15.92 & & \\
\hline$\left[\mathrm{Sn}\left(\mathrm{P}_{2} \mathrm{O}_{7}\right) \mathrm{H}_{2}\right]$ & 17.47 & & \\
\hline$\left[\mathrm{Sn}\left(\mathrm{P}_{2} \mathrm{O}_{7}\right)_{2}\right]^{6-}$ & 16.27 & 0.093 & -0.847 \\
\hline$\left[\mathrm{Sn}\left(\mathrm{P}_{2} \mathrm{O}_{7}\right)_{2} \mathrm{H}\right]^{5-}$ & 22.31 & & \\
\hline$\left[\mathrm{Sn}\left(\mathrm{P}_{2} \mathrm{O}_{7}\right)_{2} \mathrm{H}_{2}\right]^{4-}$ & 26.79 & & \\
\hline$\left[\mathrm{Sn}\left(\mathrm{P}_{2} \mathrm{O}_{7}\right)_{2} \mathrm{H}_{3}\right]^{3-}$ & 30.07 & & \\
\hline$\left[\mathrm{Sn}\left(\mathrm{P}_{2} \mathrm{O}_{7}\right)_{2} \mathrm{H}_{4}\right]^{2-}$ & 31.58 & & \\
\hline$\left[\mathrm{Sn}\left(\mathrm{P}_{2} \mathrm{O}_{7}\right) \mathrm{OH}\right]^{3-}$ & 5.32 & & \\
\hline$\left[\mathrm{Sn}\left(\mathrm{P}_{2} \mathrm{O}_{7}\right)(\mathrm{OH})_{2}\right]^{2-}$ & -4.77 & & \\
\hline$\left[\mathrm{Sn}\left(\mathrm{P}_{2} \mathrm{O}_{7}\right)_{2} \mathrm{OH}\right]^{5-}$ & 7.04 & & \\
\hline$\left[\mathrm{Ni}\left(\mathrm{NH}_{2} \mathrm{CH}_{2} \mathrm{COO}\right)\right]^{+}$ & 5.60 & & \\
\hline$\left[\mathrm{Ni}\left(\mathrm{NH}_{2} \mathrm{CH}_{2} \mathrm{COO}\right)_{2}\right]$ & 10.40 & 0.009 & -0.716 \\
\hline$\left[\mathrm{Ni}\left(\mathrm{NH}_{2} \mathrm{CH}_{2} \mathrm{COO}\right)_{3}\right]^{-}$ & 13.80 & 0.057 & -0.716 \\
\hline$\left[\mathrm{Ni}\left(\mathrm{P}_{2} \mathrm{O}_{7}\right)\right]^{2-}$ & 5.80 & 0.005 & -0.716 \\
\hline$\left[\mathrm{Ni}\left(\mathrm{P}_{2} \mathrm{O}_{7}\right)_{2}\right]^{6-}$ & 7.40 & 0.029 & -0.716 \\
\hline
\end{tabular}




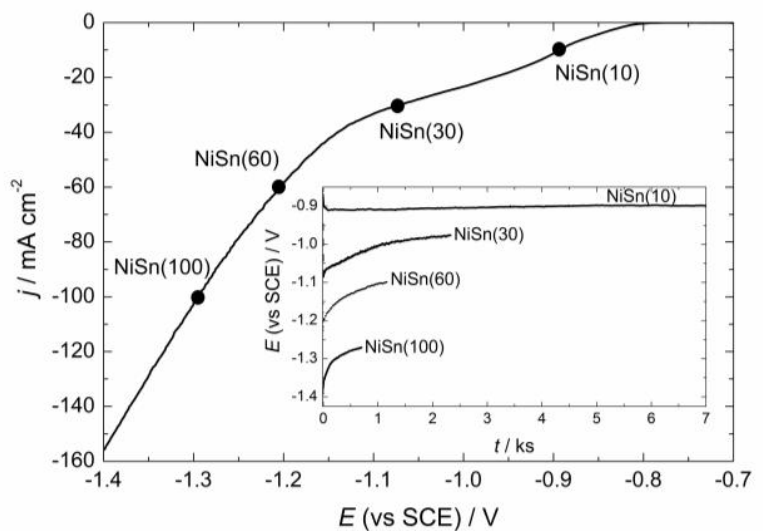

Fig. 7. Polarization curve for deposition of the NiSn alloy onto $\mathrm{Ni} 40$ mesh electrode from the solution $0.1 \mathrm{M} \mathrm{SnCl}_{2}$ $+0.3 \mathrm{M} \mathrm{NiCl}_{2}+0.6 \mathrm{M} \mathrm{K}_{4} \mathrm{P}_{2} \mathrm{O}_{7}+0.3 \mathrm{MNH}_{2} \mathrm{CH}_{2} \mathrm{COOH}$ at pH 6.7. Inset: $E$ vs. $t$ responses for deposition of samples $\mathrm{NiSn}(10), \mathrm{NiSn}(30), \mathrm{NiSn}(60)$ and $\mathrm{NiSn}(100)$.
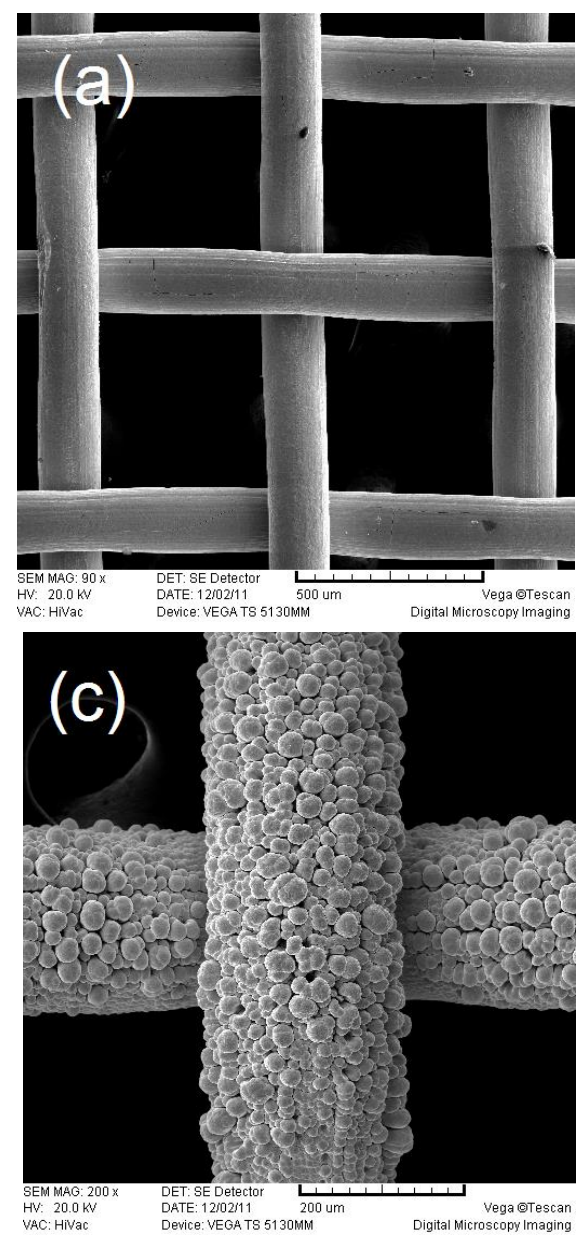

Fig. 8. SEM's of the surface (a) and the cross-section (b) of the NiSn(10) cotaing. Typical SEM's of the surface (c) and the cross-section (d) of the rough NiSn cotaings (NiSn(30), NiSn(60) and NiSn(100)).

\subsection{Polarization characteristics for the HER onto NiSn coatings}

Polarization characteristics for the HER onto NiSn coatings in 32 mass \% NaOH at $90{ }^{\circ} \mathrm{C}$ are presented in Fig. 9 for all investigated samples:

\subsection{Morphology of deposited NiSn alloy coatings}

Two types of morphologies are characteristic for the deposited NiSn coatings. Flat deposits, characterized by the presence of cracks, obtained at $j=-10 \mathrm{~mA} \mathrm{~cm}^{-2}$ (Fig. 8a,b) and rough, porous, deposits obtained at higher cathodic current densities (Fig. 8c,d). XRD analysis showed that in all investigated samples the hexagonal $\mathrm{Ni}_{(1+x)} \mathrm{Sn}$ $(0<x<0.5)$ phase is dominant with small amount of pure $\mathrm{Ni}$ phase [10]. The percentage of $\mathrm{Ni}$ was found to increase in the deposited samples with the increase of the deposition current density from about 50 at. $\%$ at $j=-10 \mathrm{~mA} \mathrm{~cm}^{-2}$ to about 75 at. $\%$ at $j=-100 \mathrm{~mA} \mathrm{~cm}^{-2}$.
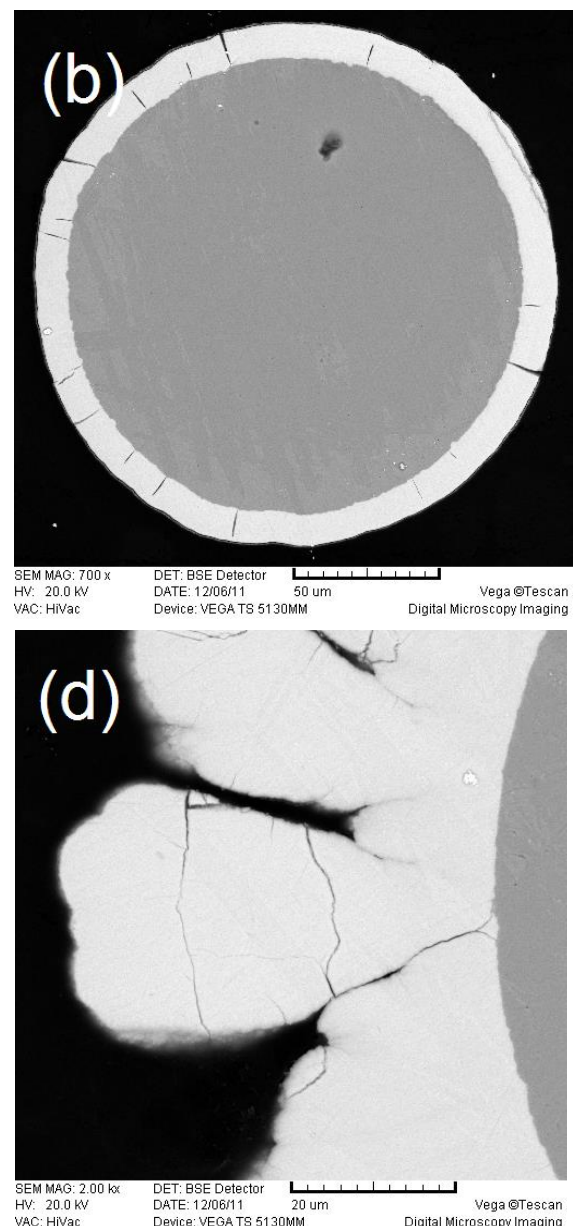

NiSn(10); NiSn(30); NiSn(60); NiSn(100); DN cathode. In Fig. 9a are presented measured polarization curves, while in Fig. 9b are presented polarization curves corrected for the IR drop (as explained in section 3.7.). As can be seen the overvoltage for the HER decreases with increasing 
deposition current density. As in the case of samples deposited onto Ni plate [10] this decrease is due to the change in chemical and phase composition of the NiSn coatings, as well as due to the change in their morphology. Polarization characteristics for the HER onto commercial DN electrode are also presented in the same figure. In the region of current densities lower than $0.2 \mathrm{~A}$ $\mathrm{cm}^{-2}$ the overvoltage for the HER onto DN electrode is lower than that on all NiSn samples (Fig. 9b). At higher current densities the overvoltage for the HER onto NiSn samples NiSn(30), $\mathrm{NiSn}(60)$ and $\mathrm{NiSn}(100)$ is lower than that onto DN (Fig. 9b). Such behavior indicates that rough NiSn coatings could be promising replacement for the commercial DN cathode.
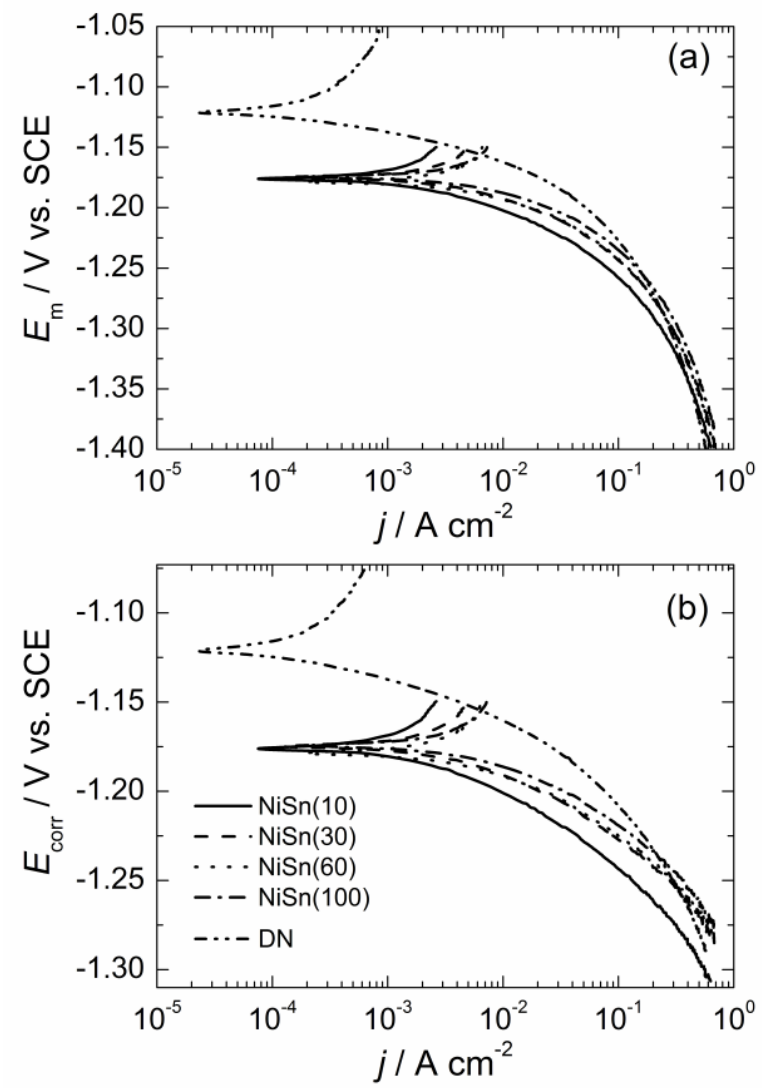

Fig. 9. (a) Polarization curves for the HER recorded at a sweep rate of $1 \mathrm{mV} \mathrm{s}^{-1}$ in 32 mass $\% \mathrm{NaOH}$ at $90^{\circ} \mathrm{C}$. (b) The same polarization curves corrected for the IR drop. Samples: NiSn(10) $-j=-10 \mathrm{~mA}$ $\mathrm{cm}^{-2}$ ( $\square$ ); $\mathrm{NiSn}(30)-j=-30 \mathrm{~mA} \mathrm{~cm}{ }^{-2}(\mathrm{O}) ; \mathrm{NiSn}(60)$ $-j=-60 \mathrm{~mA} \mathrm{~cm}{ }^{-2}(\triangle) ; \mathrm{NiSn}(100)-j=-100 \mathrm{~mA}$ $\mathrm{cm}^{-2}(\nabla) ; D N$ - commercial De Nora's electrode $(\diamond)$.

Considering the shape of the polarization curves it can be seen that the linear Tafel region cannot be detected at all polarization curves. It is generally accepted that the first step in the HER is the Volmer (discharge) reaction which involves the formation of adsorbed hydrogen $\left(\mathrm{H}_{\mathrm{ads}}\right)$ intermediate followed by either the Heyrovsky step, or the Tafel (recombination) step [30,31]. Usually, it is assumed that the forward rate of one of these reaction steps is rate-determining in the overall reaction mechanism. In such a case the HER can be described by linear Tafel relationships and constant reaction orders. However, there is a potential interval in which the overall rate of the HER is under mixed control by the kinetics of the first and the second step. In this case the Tafel relationship is not linear. It is also important to emphasize that the linear Tafel relationship cannot be achieved in the potential region in which the surface coverage by the electroactive intermediate is changing appreciably with potential.

All investigated electrodes exhibit high catalytic activity resulting in the current density change for four decades in a very narrow potential range of about $100 \mathrm{mV}$. The fact that the impedance diagrams consist of two overlapping semi-circles (see Figs. 11-13) with the semicircle at the lowfrequency end being related to circuit elements $R_{\mathrm{p}}$ and $C_{p}$, clearly indicates that non-linear Tafel relationship for the HER at investigated electrodes is caused by the change of the surface coverage of the $\mathrm{H}_{\mathrm{ads}}$ intermediate with potential $[30,31]$.

\section{7. $S L T$}

The CV's recorded during the SLT procedure are characterized with the behavior of pure $\mathrm{Ni}$ electrode, as in the case of $\mathrm{DN}$ and $\mathrm{Ni}-\mathrm{MoO}_{2}$ electrodes (Figs. 3 and 4). The only difference was the absence of the peaks IIla and IIIc, since in the NiSn alloy samples neither of the metal oxides (formed at anodic potentials) has been reduced in the investigated potential range.

Comparing the values of potential (corrected for the IR drop) recorded at the current density $j=$ $0.3 \mathrm{~A} \mathrm{~cm}^{-2}$ as a function of the number of cycles, it appears that the activity for the HER for all cathodes decreases in a similar way with the number of cycles, being lower for about $20-25 \mathrm{mV}$ after 25 cycles. The best characteristics were obtained for the sample NiSn(100), while the coatings NiSn(30), NiSn(60) and NiSn(100) possessed lower overvoltage for the HER before and after the SLT in comparison with that for DN electrode, as shown in Fig. 15a.

\subsection{EIS results}

The EIS results obtained for all NiSn samples were different, but it was possible to fit all experimental results with the equivalent circuit shown in Fig. 10, where the parameters were defined as: $R_{\mathrm{s}}$ - solution resistance; $R_{\mathrm{ct}}$ - charge transfer resistance; $C P E_{d l}$ - constant phase element for the double layer; $R_{\mathrm{p}}$ and $C_{\mathrm{p}}$ are complex functions of the kinetic parameters. 


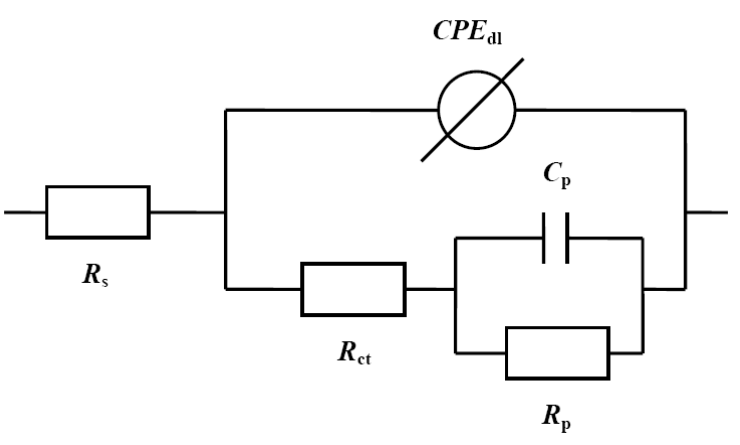

Fig. 10. Equivalent circuit for fitting EIS results: $R_{s}$ - solution resistance; $R_{c t}$ - charge transfer resistance; $C P E_{d l}$ - constant phase element for the double layer; $R_{p}$ and $C_{p}$ are complex functions of the kinetic parameters.

For sample NiSn(10) well defined two semicircles characterized the Nyquist plots obtained before and after applying SLT procedure, as can be seen in Fig. 11, without deviation from the shape of the semi-circle at the highest frequencies (inset of Fig. 11). As in the case of all other NiSn samples both semi-circles increased with increasing the number of cycles (in Fig. 11 are shown Nyquist plots obtained before and after applying 25 cycles). Experimental results are presented with squares, circles and triangles, while the fitting results are presented with solid, dashed and dotted lines. Nyquist plots for the other NiSn samples, (NiSn(30), NiSn(60) and $\mathrm{NiSn}(100))$, are also characterized with two well defined semi-circles, the one at higher frequencies corresponding to the parameters $R_{\mathrm{ct}}$ and $C P E_{\mathrm{dl}}$ and the other one at low frequencies corresponding to the parameters $R_{\mathrm{p}}$ and $C_{P}$ (in Fig. 12 are presented Nyquist plots for sample $\mathrm{NiSn}(60))$. At the highest frequencies, between $1 \mathrm{kHz}$ and $10 \mathrm{kHz}$ (inset of Fig. 12), Nyquist plots are characterized by linear dependence of $Z$ " vs. $Z$ ', with the slope of about 1 , indicating the presence of pores [32-36]. The EIS response for porous electrodes has been theoretically treated $[33,34]$ and experimentally investigated $[35,36]$ by Lasia et al. [33-36], using the first model defined by R. de Levi in 1967 [32]. Characteristic of all, theoretical treatments [33,34] and experimental investigations $[35,36]$ is a linear dependence of $Z^{\prime \prime}$ vs. $Z^{\prime}$, with the slope of about 1 at the highest frequencies. Hence, the ohmic resistance (used for IR drop correction) was obtained by the extrapolation of $Z$ " vs. $Z$ ' linear dependence to the $Z^{\prime}$ ' axes (as marked in the inset of Fig. 12 with the dashed line). Nyquist plots recorded for the DN electrode before cycling and after 25 cycles are presented in Fig. 13. For this electrode two semi-circles can also be detected, with small difference between Nyquist plots obtained before cycling and after 25 cycles.

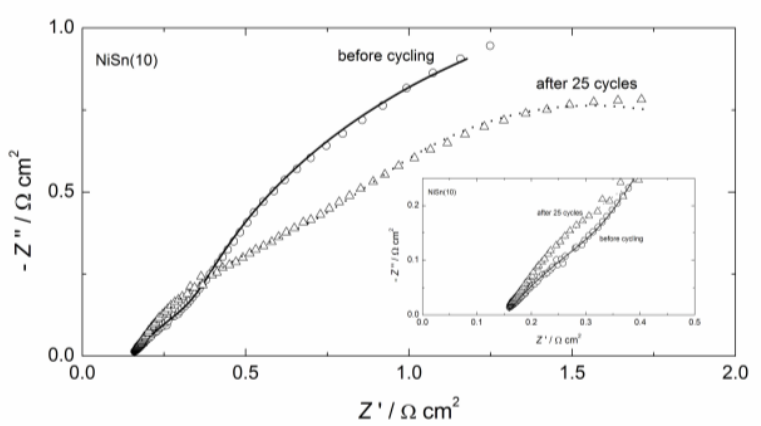

Fig. 11. Nyquist plots for sample NiSn(10) before cycling $(\square)$ and after 25 cycles $(\triangle)$.

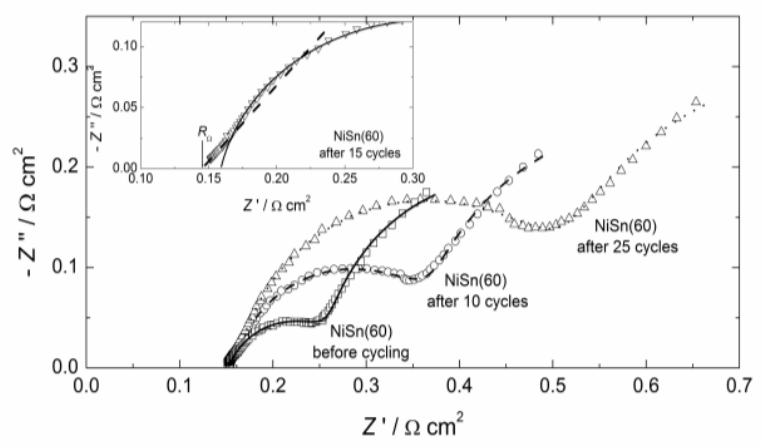

Fig. 12. Typical Nyquist plots for samples NiSn(30), NiSn(60) and NiSn(100) (presented results for sample NiSn(60)) before cycling ( $\square$ ), after 10 cycles $(\bigcirc)$ and after 25 cycles $(\triangle)$. Inset: High frequency end for samples NiSn(30), NiSn(60) and NiSn(100) (presented results for sample NiSn(60)).

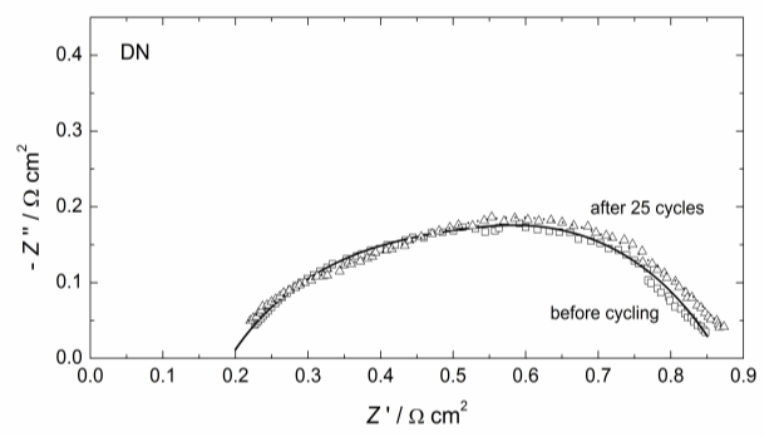

Fig. 13. Nyquist plots for commercial De Nora's electrode $(D N)$ before cycling $(\square)$ and after 25 $\operatorname{cycles}(\triangle)$.

Parameters of the EIS measurements fitting, $C_{\mathrm{dl}}, C_{\mathrm{P}}$ and $\left(R_{\mathrm{ct}}+R_{\mathrm{p}}\right)$ as a function of the number of cycles are presented in Fig. 14. The value of $C_{\mathrm{dll}}$ was determined from the relation [11],

$$
C_{\mathrm{dl}}=\left[Y_{\mathrm{dl}} R_{\mathrm{ct}}{ }^{\left(1-\alpha_{\mathrm{dl}}\right)}\right]^{\frac{1}{\alpha_{\mathrm{dl}}}}
$$

since the parameters $C P E_{\mathrm{dl}}$ and $R_{\mathrm{ct}}$ are connected in parallel. 

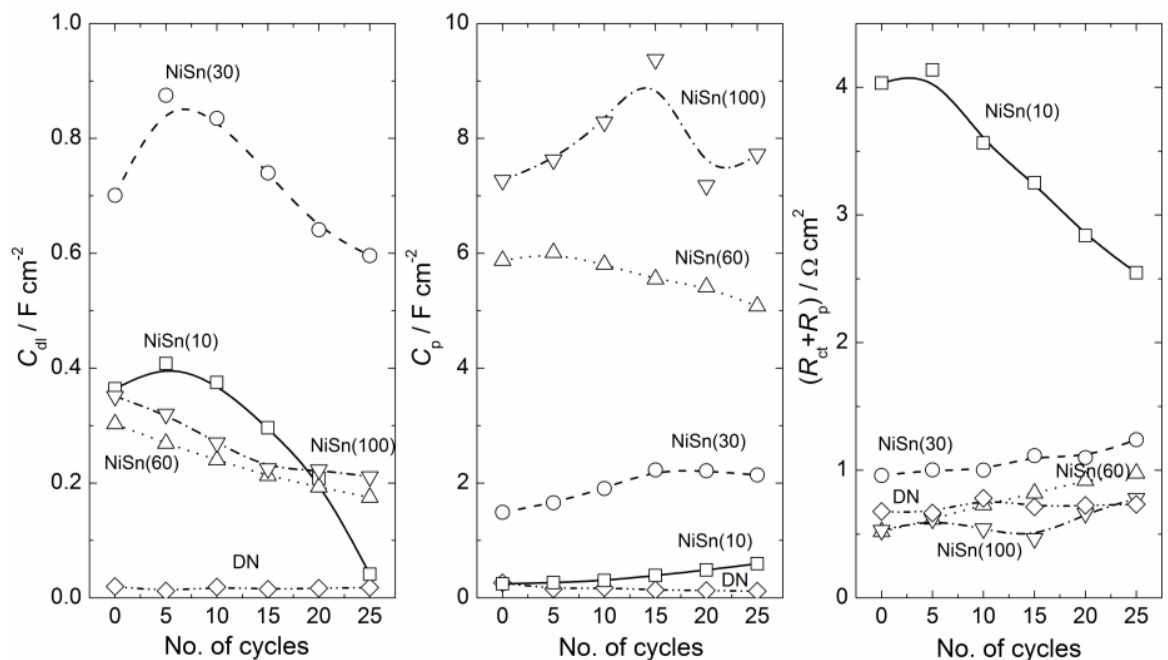

Fig. 14. Parameters $C_{d l}, C_{p}$ and $\left(R_{c t}+R_{p}\right)$ obtained by the fitting procedure using equivalent circuit presented in Fig. 10 as a function of the number of cycles performed during the SLT for all investigated electrodes.
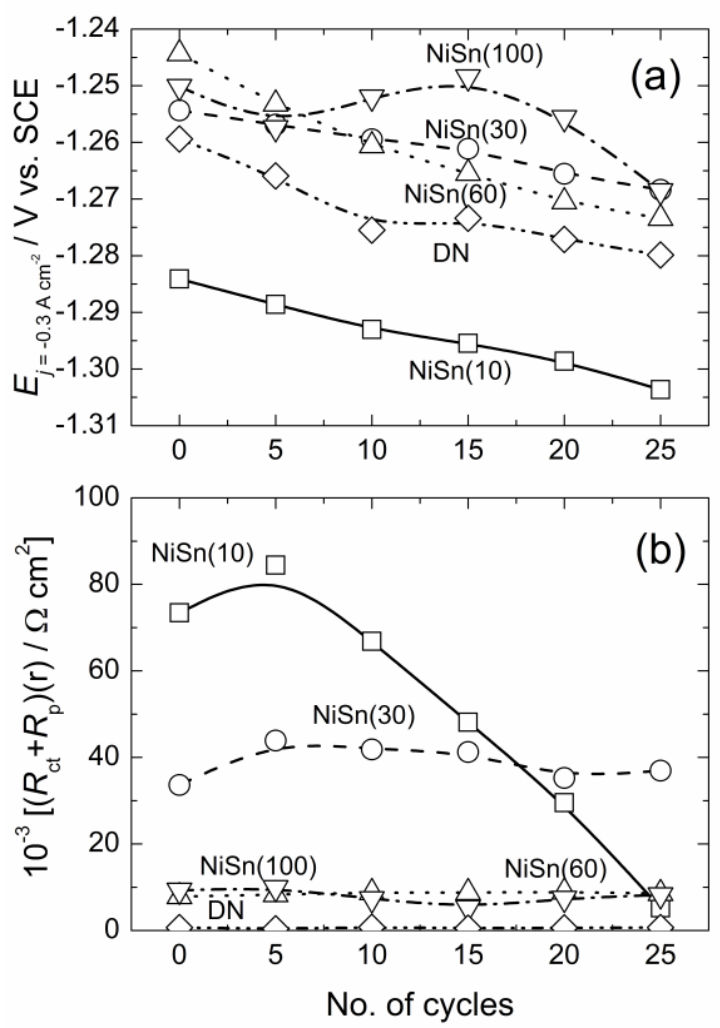

Fig. 15. (a) SLT results, represented as potential (corrected for the IR drop) for the HER at $j=-0.3 \mathrm{~A}$ $\mathrm{cm}^{-2}$ as a function of the number of cycles for all investigated electrodes. (b) The values of

$\left(R_{c t}+R_{p}\right)(r)$ as a function of the number of cycles for all investigated electrodes.

Considering Fig. 14 it can be seen that the value of $\left(R_{\mathrm{ct}}+R_{\mathrm{p}}\right)$ for $\mathrm{DN}$ electrode practically doesn't change with the number of cycles, which is in accordance with the EIS results presented in Fig. 13 (very small change of the Nyquist plot after 25 cycles), indicating no change in the catalytic activity of DN electrode for the HER at $-1.2 \mathrm{~V}$. Similar behavior is obtained for the samples $\mathrm{NiSn}(30)$, $\mathrm{NiSn}(60)$ and $\mathrm{NiSn}(100)$, with the values of $\left(R_{\mathrm{ct}}+\right.$ $R_{\mathrm{p}}$ ) for these samples being close to those for DN cathode. Considering Fig. $15 \mathrm{a}$ it is clear that all investigated cathodes lose their catalytic activity for the HER during the SLT. The roughness factor could be obtained as the ratio between measured $C_{\mathrm{dl}}$ (obtained by fitting procedure and Eqn. (1)) and $C_{\mathrm{dl}}($ ideal $)=20 \mu \mathrm{F} \mathrm{cm}^{-2}$. Multiplying fitted values of $\left(R_{\mathrm{ct}}+R_{\mathrm{p}}\right)$ by the roughness factor the real values of the $\left(R_{\mathrm{ct}}+R_{\mathrm{p}}\right)(\mathrm{r})$, could be obtained. These values are presented in Fig. 15b. As can be seen the lowest value of the $\left(R_{\mathrm{ct}}+R_{\mathrm{p}}\right)(\mathrm{r})$ is obtained for $\mathrm{DN}$ electrode, confirming that this cathode should possess the highest current density at a given potential $(-1.2 \mathrm{~V})$, which is in accordance with the polarization curve measurements (Fig. 9). At the same time, the samples $\mathrm{NiSn}(30), \mathrm{NiSn}(60)$ and $\mathrm{NiSn}(100)$ possessed lower overvoltage for the HER at the current density $j=-0.3 \mathrm{~A} \mathrm{~cm}^{-2}$. Hence, it could be concluded that the EIS measurements and polarization curve measurements are in accordance with the SLT measurements (dependence of $E$ corrected for the IR drop recorded at $j=-0.3 \mathrm{~A}$ $\mathrm{cm}^{-2}$ vs. number of cycles).

\subsection{SEM and EDS analysis of the NiSn samples before and after the SLT}

The best example of the influence of SLT on the morphology and composition of all samples is obtained for sample NiSn(10), as shown on the back-scatter SEM-EDS in Fig. 16. The SEM-EDS analysis of the surface of this sample before the $\mathrm{SLT}$ is shown in Fig. 16c. No oxygen has been detected on the sample surface, while its surface is characterized by the presence of cracks. The backscatter SEM-EDS analysis of the same sample after the SLT is presented in Fig. 16a and b, for two different parts of the surface characteristic for this sample. A common characteristic for both surfaces is the presence of high percentage of oxygen, 
confirming that the surfaces were oxidized during the SLT, as it was the case for all other samples. In Fig. 16a white and grey parts of the surface could be detected. Grey parts are characterized with the higher percentages of $\mathrm{Sn}$ and $\mathrm{O}$ with practically no $\mathrm{Ni}$ (spectra 1,2 and 5), most likely corresponding to $\mathrm{SnO}_{2}$. White parts contain lower percentage of $\mathrm{O}$ and equal percentages of $\mathrm{Ni}$ and $\mathrm{Sn}$ (spectra 3 and 4 ), indicating most likely oxidized surface of the

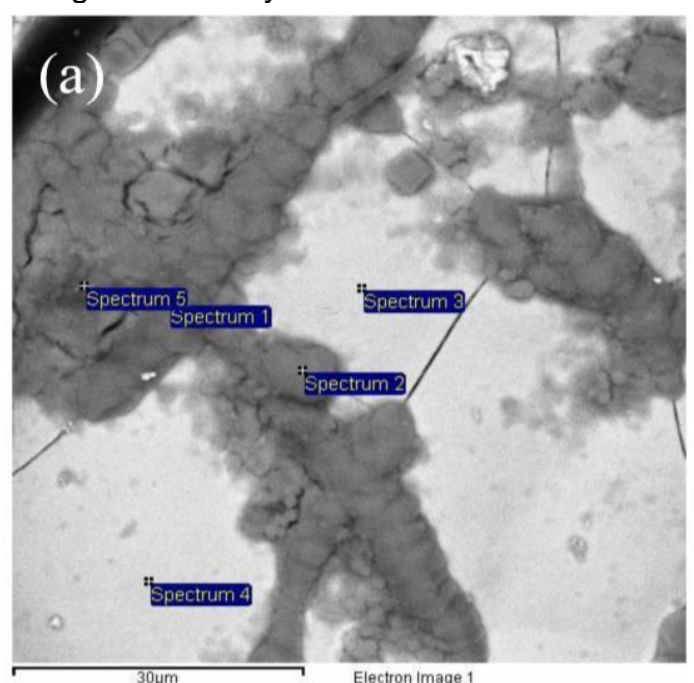

\begin{tabular}{|l|l|l|l|l|}
\hline Spectrum & In stats. & $\mathrm{O} /$ at. $\%$ & $\mathrm{Ni} /$ at. $\%$ & $\mathrm{Sn} /$ at. $\%$ \\
\hline Spectrum 1 & Yes & 87.36 & 0.33 & 12.31 \\
\hline Spectrum 2 & Yes & 89.92 & 0.32 & 9.76 \\
\hline Spectrum 3 & Yes & 33.32 & 32.00 & 34.67 \\
\hline Spectrum 4 & Yes & 38.28 & 30.27 & 31.46 \\
\hline Spectrum 5 & Yes & 86.10 & 1.25 & 12.65 \\
\hline
\end{tabular}

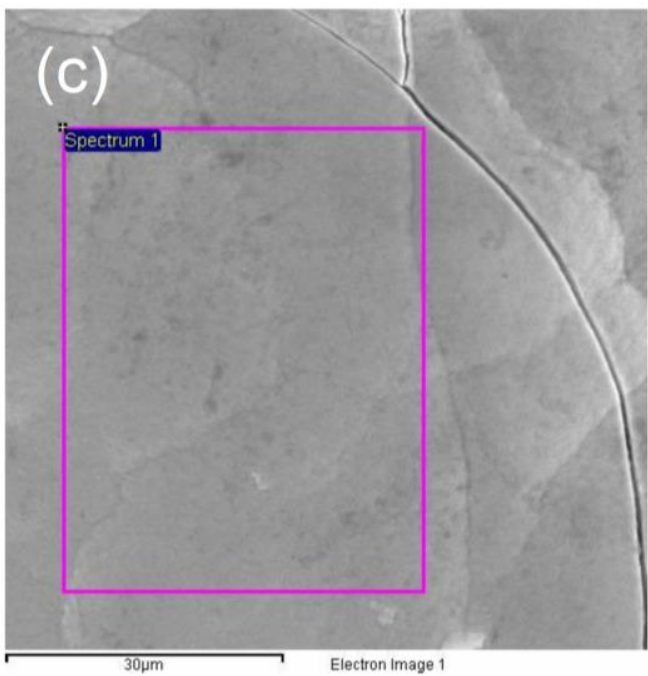

\begin{tabular}{|c|c|c|c|}
\hline Spectrum & \multicolumn{3}{|c|}{ In stats. $\mathrm{Ni} /$ at. $\%$ Sn / at. $\%$} \\
\hline Spectrum 1 & Yes & 42.75 & 57.25 \\
\hline Mean & & 42.75 & 57.25 \\
\hline Std. deviation & & 0.00 & 0.00 \\
\hline Max. & & 42.75 & 57.25 \\
\hline Min. & & 42.75 & 57.25 \\
\hline
\end{tabular}

hexagonal $\mathrm{Ni}_{(1+x)}$ Sn $(0<x<0.5)$ phase [10]. It should be emphasized that the presence of oxygen on the cross-section of all samples could not be detected, confirming that the oxidized layer is very thin, of the order of nanometers. The same conclusion, concerning the presence of oxygen on their surfaces after the SLT, is valid for all other NiSn samples.
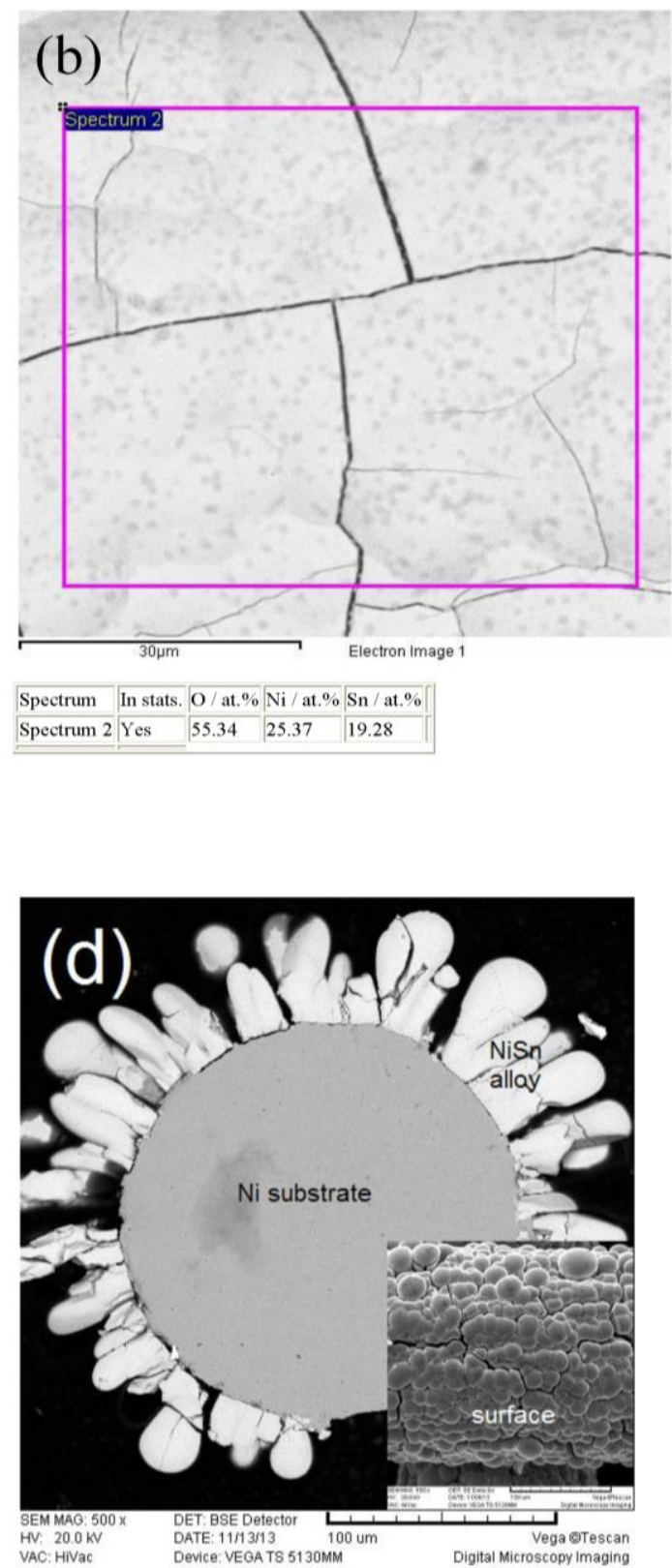

Fig. 16. The SEM-EDS analysis of a surface of the sample NiSn(10) after the SLT (a and b). The SEM-EDS analysis of a surface of the sample NiSn(10) before the SLT (c). The SEM's of the cross-section and the surface (inset) characteristic for samples NiSn(30), NiSn(60) and NiSn(100) (d). 
Concerning Nyquist plots presented in Figs. 1113 it could be stated that the EIS results are in good agreement with the SEM-EDS analysis presented in Fig. 16. The sample NiSn(10), Fig. $16 \mathrm{a}-\mathrm{c}$, is characterized with cracks and relatively flat surface. Accordingly, the high frequency end of the Nyquist plots does not indicate deviation from a semi-circle's behavior. Characteristic cross-section and appearance of the surface (inset of Fig. 16d) of samples $\mathrm{NiSn}(30), \mathrm{NiSn}(60)$ and $\mathrm{NiSn}(100)$, before and after SLT is presented in Fig. 16d. The presence of large pores is in accordance with the linear dependence of $Z$ " vs. $Z^{\prime}$ at the high frequency end on the Nyquist diagrams recorded for these samples, characteristic for porous electrodes [32-36].

\section{CONCLUSIONS}

From the results presented in this work it could be concluded that both, $\mathrm{Ni}-\mathrm{MoO}_{2}$ composite coatings and NiSn deposited alloys show high catalytic activity for the HER. Among high catalytic activity, some samples of each coating showed better performance during the SLT than the commercial DN cathode, confirming that both coatings could be considered as promising replacements for the commercial cathodes in the chlor-alkali industry.

\section{Acknowledgements}

This work was financially supported by the Ministry of Education, Science and Technological Development of the Republic of Serbia through the Project No. 172054/2011.

The authors also wish to express their gratitude to the Department of Research and Development of De Nora Industries S.p.A. for providing equipment for electrodeposition of $\mathrm{Ni}-\mathrm{MoO}_{2}$ coatings and commercial De Nora's $\mathrm{Ni}_{-} \mathrm{RuO}_{2}$ cathodes.

\section{REFERENCES}

[1] Nagamura M, Ukihashi H, Shiragami O, (1983), Modern Chlor-Alkali Technology, In: C. Jackson (Ed.), vol. 2, Ellis Horwood, Chichester, p. 61.

[2] Grove DE, (1986), Modern Chlor-Alkali Technology, In: K. Wall (Ed.), vol. 3, Ellis Horwood, Chichester, p. 250.

[3] S. Trasatti, (1992), Electrocatalysis of hydrogen evolution: Progress in cathode activation, In: $\mathrm{H}$. Gerischer, C.W. Tobias (Eds.), Advances in electrochemical science and engineering, Weinheim, Wiley-VCH Verlag GmbH, pp. 1-85.

[4] Iwakura C, Tanaka M, Nakamatsu S, Noue H, Matsuoka M, Furukawa N, (1995), Electrochemical properties of $\mathrm{Ni} /(\mathrm{Ni}+\mathrm{RuO} 2)$ active cathodes for hydrogen evolution in chlor-alkali electrolysis, Electrochim. Acta, 40, 977-82.
[5] Antozzi AL, Bargioni C, Jacopetti L, Musiani M, Vazquez-Gomez L, (2008), EIS study of the service life of activated cathodes for the hydrogen evolution reaction in the chlor-alkali membrane cell process, Electrochim. Acta, 53, 7410-7416.

[6] Jović VD, Lačnjevac U, Jović BM, Krstajić NV, (2012), Service life test of non-noble metal composite cathodes for hydrogen evolution in sodium hydroxide solution, Electrochim. Acta, 63, 124-130.

[7] Jović VD, Lačnjevac UČ, Jović BM, Gajić-Krstajić LjM, Krstajić NV, (2013), Ni-MoO2 composite cathodes for hydrogen evolution in alkaline solution. Effect of aging of the electrolyte for their electrodeposition, J. Serb. Chem. Soc., 78, 689-700.

[8] Krstajić NV, Lačnjevac U, Jović BM, Mora S, Jović VD, (2011), Non-noble metal composite cathodes for hydrogen evolution. Part II: The Ni-MoO2 coatings electrodeposited from nickel chlorideammonium chloride bath containing $\mathrm{MoO} 2$ powder particles, Int. J. Hydrogen Energy, 36, 6450-6461.

[9] Lačnjevac UČ, Jović BM, Jović VD, Krstajić NV, (2012), Determination of kinetic parameters for the hydrogen evolution reaction on the electrodeposited $\mathrm{Ni}-\mathrm{MoO} 2$ composite coating in alkaline solution, J. Electroanal. Chem. 677, 31-40.

[10] Jović VD, Lačnjevac U, Jović BM, Karanović Lj, Krstajić NV, (2012), Ni-Sn coatings as cathodes for hydrogen evolution in alkaline solution. Chemical composition, phase composition and morphology effects, Int. J. Hydrogen Energy, 37, 17882-17891.

[11] Jović BM, Lačnjevac UČ, Krstajić NV, Jović VD, (2013), Ni-Sn coatings as cathodes for hydrogen evolution in alkaline solutions, Electrochim. Acta, 114, 813-818.

[12] Krstajić NV, Jović VD, Gajić-Krstajić Lj, Jović BM, Antozzi AL, Martelli GN, (2008), Electrodeposition of $\mathrm{Ni}-\mathrm{Mo}$ alloy coatings and their characterization as cathodes for hydrogen evolution in sodium hydroxide solution, Int. J. Hydrogen Energy, 33, 3676-3687.

[13] Dmochowska A, Czerwinski A, (1998), Behavior of a nickel electrode in the presence of carbon monoxide, J. Solid State Electrochem., 2, 16-23.

[14] Yau SL, Fan FRF, Moffat TP, Bard AJ, (1994), In situ Scanning Tunneling Microscopy of $\mathrm{Ni}(100)$ in 1 $\mathrm{M} \mathrm{NaOH}$, J. Phys. Chem., 98, 5493-5499.

[15] Beden B, Bewick A, (1988), The anodic layer on nickel in alkaline solution: an investigation using in situ IR spectroscopy, Electrochim. Acta, 33, 16951698.

[16] French HM, Henderson MJ, Hillman AR, Vieil E, (2001), Ion and solvent transfer discrimination at a nickel hydroxide film exposed to $\mathrm{LiOH}$ by combined electrochemical quartz crystal microbalance (EQCM) and probe beam deflection (PBD) techniques, J. Electroanal. Chem., 500, 192-207.

[17] French HM, Henderson MJ, Hillman AR, Vieil E, (2002), Temporal resolution of ion and solvent transfers at nickel hydroxide films exposed to $\mathrm{LiOH}$, Solid State Ionics, 150, 27-37. 
[18] Hu YN, Scherson DA, (1997), Potential-Induced Plastic Deformations of Nickel Hydrous Electrodes in Alkaline Electrolytes: An in Situ Atomic Force Microscopy Study, J. Phys. Chem. B, 101, 53705376.

[19] Haring P, Kotz R, (1995), Nanoscale thickness change of nickel hydroxide films, J. Electroanal. Chem., 386, 273-277.

[20] Bode H, Dehmelt K, Witte J, (1966), Zur kenntnis der nickelhydroxidelektrode-I.Über das nickel (II)hydroxidhydrat, Electrochim. Acta, 11, 1079-1087.

[21] Tavares AC, Trasatti S, (2000), Ni+RuO2 codeposited electrodes for hydrogen evolution, Electrochim. Acta, 45, 4195-4202.

[22] Vazquez-Gomez L, Cattarin S, Guerriero P, Musiani $M,(2009)$, Influence of deposition current density on the composition and properties of electrodeposited $\mathrm{Ni}+\mathrm{RuO} 2$ and $\mathrm{Ni}+\mathrm{IrO} 2$ composites, J. Electroanal. Chem., 634, 42-48.

[23] K. Juodkazis, J. Juodkazyte, R. Vilkauskaite, V. Jasulaitiene, (2008), Nickel surface anodic oxidation and electrocatalysis of oxygen evolution, J. Solid State Electrochem., 12, 1469-1479.

[24] Handbook of Chemistry and Physics (1976-1977) 57th edition, Weast RC (ed), CRC Press Inc., Cleveland, pp. D141-146.

[25] Jović VD, Tošić N, (1998), Qualitative and quantitative assessment of phases in electrodeposited $\mathrm{Ni}+$ Cd alloys by the ALSV technique, J. Electroanal. Chem., 441, 69-76.

[26] J. A. Daen, (1999), Lange's Handbook of Chemistry, 15th Edition, McGraw-Hill Inc., New York.

[27] Duffield JR, Williams DR, Kron I, (1991), Speciation studies of the solubility and aqueous solution chemistry of tin(II) - and tin (IV) pyrophosphate complexes, Polyhedron, 10, 377-387.
[28] Lačnjevac U, Jović BM, Jović VD, (2012), Electrodeposition of $\mathrm{Ni}, \mathrm{Sn}$ and $\mathrm{Ni}-\mathrm{Sn}$ Alloy Coatings from Pyrophosphate-Glycine Bath, J. Electrochem. Soc., 159, D310-D318.

[29] C. Han, Q. Liu and D. G. Ivey, (2008), Kinetics of Sn electrodeposition from Sn(II)-citrate solutions, Electrochim. Acta, 53, 8332-8340.

[30] Harrington DA, Conway BE, (1987), ac impedance of faradaic reactions involving electrosorbed intermediates - I. Kinetic theory, Electrochim. Acta, 32, 1703-1712.

[31] Bai L, Harrington DA, Conway BE, (1987), Behavior of overpotential - deposited species in faradaic reactions - II. ac impedance measurements on $\mathrm{H} 2$ evolution kinetics at activated and unactivated $\mathrm{Pt}$ cathodes, Electrochim. Acta, 32, 1713-1731.

[32] De Levie R, (1967), Electrochemical response of porous and rough electrodes. In: Delahay $\mathrm{P}$, Tobias CW, (Eds.), Advances in Electrochemistry and Electrochemical Engineering, vol. 6, New York, Interscience, pp. 329-397.

[33] Lasia A, (1999), Electrochemical Impedance Spectroscopy and its Applications. In: Conway BE, Bockris JO'M, White RE, (Eds.), Modern Aspects of Electrochemistry, vol. 32, New York, Kluwer Academic/Plenum Publishers, pp. 210-240.

[34] A. Lasia, (2009), Modeling of Impedance of Porous Electrodes, in: M. Schlesinger (Ed.), Modern Aspects of Electrochemistry, vol. 43, Kluwer Academic/Plenum Publishers, New York, pp. 67137.

[35] Los P, Lasia A, Menard H, (1993), Impedance studies of porous lanthanum-phosphate-bonded nickel electrodes in concentrated sodium hydroxide solution, J. Electroanal. Chem., 360, 101-118.

[36] Lasia A, (1995), Impedance of porous electrodes, J. Electroanal. Chem., 397, 27-33.

\section{IZVOD}

\section{ELEKTROHEMIJSKI ISTALOŽENE PREVLAKE NA BAZI Ni I NEPLEMENITIH METALA KAO KATODE ZA IZDVAJANJE VODONIKA U HLOR-ALKALNOJ ELEKTROLIZI}

Reakcija izdvajanja vodonika ispitivana je na dva tipa prevlaka od neplemenitih metala dobijenih elektrohemijskim taloženjem: kompozitne prevlake sa uključkom $\mathrm{MoO}_{2}$ čestica i prevlake od NiSn legura. Cilj rada je bio dobijanje katoda koje bi mogle da zamene postojeće katode na bazi plemenitih metala (komercijalne $\mathrm{Ni}_{-} \mathrm{RuO}_{2}$ katode, proizvođač De Nora Industrija) u industrijskom procesu hlor-alkalne elektrolize. Neki uzorci oba tipa katoda pokazali su bolju katalitičku aktivnost za reakciju izdvajanja vodonika od komercijalne katode u uslovima industrijske primene: 32 mas. $\% \mathrm{NaOH}, 90{ }^{\circ} \mathrm{C} i j=-0.3 \mathrm{~A}$ $\mathrm{cm}^{-2}$. Imajući u vidu da bolja katalitička aktivnost za reakciju izdvajanja vodonika nije jedini kriterijum za uspešnu primenu u industrijskoj elektrolizi, ispitivan je vek trajanja oba tipa katoda, definisan određenom procedurom. Pokazano je takođe da neki uzorci oba tipa katoda mogu naći primenu u industrijskom postupku hlor-alkalne elektrolize, jer su pokazali bolje osobine od komercijalne katode pri ispitivanju veka trajanja katoda.

Ključne reči: izdvajanje vodonika, kompozitne $\mathrm{Ni}_{-} \mathrm{MoO}_{2}$ prevlake, prevlake od NiSn legura, vek trajanja katoda

Pregledni rad

Primljeno za publikovanje: 20. 12. 2013.

Prihvaćeno za publikovanje: 21. 02. 2014. 